\title{
Epstein-Barr Virus
}

\author{
Alfred S. Evans and James C. Niederman
}

\section{Introduction}

Epstein-Barr virus (EBV), a member of the herpes group of viruses, is the cause of heterophile-positive infectious mononucleosis, of most heterophile-negative cases, and of occasional cases of tonsillitis and pharyngitis in childhood. Rarely, it may involve the liver or central nervous system as primary manifestations. This virus is strongly implicated as having a causal relationship to African Burkitt lymphoma and to nasopharyngeal cancer. High antibody titers are also present in $30-40 \%$ of cases of Hodgkin's disease, in some patients with sarcoidosis, and in systemic lupus erythematosus.

This chapter will deal with the epidemiology of EBV infections and the epidemiology of infectious mononucleosis. Infectious mononucleosis can be defined as an acute febrile illness involving children and young adults characterized clinically by sore throat and lymphadenopathy, hematologically by lymphocytosis of $50 \%$ or more, of which $10 \%$ or more are atypical, and serologically by an elevated absorbed heterophile-antibody titer and the development of EBV immunoglobulin M (IgM) and other EBV antibodies. This chapter also mentions the relationship of high antibody titers to certain chronic and malignant diseases, but the major discussion of Burkitt lymphoma and of nasopharyngeal cancer will be found in later chapters of this book.

Alfred S. Evans - WHO Serum Reference Bank, Section of International Epidemiology, Department of Epidemiology and Public Health, Yale University School of Medicine, New Haven, Connecticut . James C. Niederman · Department of Epidemiology and Public Health, Yale University School of Medicine, New Haven, Connecticut.

\section{Historical Background}

In 1889, Emil Pfeiffer of Wiesbaden, Germany, described a condition called Drüsenfieber (glandular fever), characterized by fever, adenopathy, mild sore throat, and in severe cases enlargement of the liver and spleen. ${ }^{(63,126)}$ Since Pfeiffer's original description, as well as Filatov's, ${ }^{(53,54)}$ a Russian, in 1892 , antedated by some $30-50$ years recognition of the hematological changes and the heterophile antibody, it is uncertain whether these were true infectious mononucleosis. However, his description of this febrile syndrome in older children and young adults seems best to fit this diagnosis. There is little doubt about the classic description of the disease made by Sprunt and Evans, ${ }^{(139)}$ from Johns Hopkins, in 1920. They described the disorder in young adults as we now know it, named the disease "infectious mononucleosis," and reported in detail the hematological changes. This description was followed rapidly by similar reports from other workers. ${ }^{(12,14,22,96,108)}$ A definitive presentation of hematological changes was made by Downey and McKinlay ${ }^{(28)}$ in 1923. The next major development was the discovery in 1932 of the heterophile antibody by Jonn R. Paul and William W. Bunnell ${ }^{(121)}$ of Yale University. Their report was based on an accidental observation while studying the occurrence of heterophile antibodies in rheumatic fever. This search had been initiated because of the clinical similarity of rheumatic fever and serum sickness and because of the work of Davidsohn ${ }^{(24)}$ describing the presence of heterophile antibodies in serum sickness. Among the control subjects for rheumatic 
fever patients was one who had infectious mononucleosis and was found to have a much higher heterophile antibody titer than present in any other condition. Paul and Bunnell then continued these observations in 3 additional cases of infectious mononucleosis and utilized 275 controls for comparison. Their paper also describes what they believed to be a false-positive heterophile antibody occurring in a patient with aplastic leukemia. A review of the details of this case ${ }^{(43)}$ reveals that the heterophile antibody occurred about 20 days after the administration of several units of blood, and therefore this patient may represent the first case of transfusion infectious mononucleosis. Soon after the discovery of the presence of heterophile antibodies, Davidsohn and Walker ${ }^{(23)}$ reported on the use of guinea pig kidney and of beef cells to absorb serum prior to heterophile testing in order to increase the specificity of the test. Both these procedures have withstood the test of time well and still constitute one of the major criteria of diagnosis. Regular alterations in various liver-function tests during acute infectious mononucleosis were recognized in several laboratories in the late 1940s and $1950 \mathrm{~s},{ }^{(13,35,86)}$ even though only $5 \%$ of patients had clinical jaundice. This was followed by the discovery of alterations in serum glutamic oxalacetic transaminase (SGOT) and other hepatic enzymes during the course of disease. ${ }^{(6,131,158)}$

Search for the etiological agent of infectious mononucleosis began in the 1920s, but met with little success until 1942, when Wising ${ }^{(156)}$ reported the successful transmission of classic infectious mononucleosis to a female medical student volunteer who received $250 \mathrm{ml}$ of blood from a patient ill with the acute disease. This successful experiment was not reproducible by Wising in several other attempts, nor by Bang, ${ }^{(4)}$ who carried out a similar set of volunteer experiments. In 1947 and again in 1950, additional efforts of this sort were carried out at Yale University using whole blood, serum, or throat washings. The results provided suggestive but inconclusive evidence of transmission. ${ }^{(34,36)}$ A third effort without success was reported from Yale University in 1965. ${ }^{(112)}$ Subsequent EBV antibody tests on the sera from these last experiments in 1968 revealed that all volunteers had actually been immune to infection prior to the experiment as indicated by the presence of antibody. ${ }^{(11)}$

Repeated attempts in the 1950s to isolate an in- fectious agent from the throat or blood of patients with infectious mononucleosis using several tissueculture systems, long-term cultures of lymphocytes on a feeder layer, and fluorescent antibody techniques to identify an agent were unsuccessful. ${ }^{(37)}$ Epidemiologically, the key events during this time were the observations of Hoagland, who suggested that the disease might be transmitted by kissing ${ }^{(79)}$ and that the incubation period was of the order of 30-49 days. ${ }^{(81)}$

Early in 1968, evidence first appeared that EBV was the cause of infectious mononucleosis. ${ }^{(72,114)}$ This virus, identified by Epstein et al. ${ }^{(33)}$ in a culture of African Burkitt tumor tissue, ${ }^{(128)}$ was found to be a new member of the herpes group of viruses. While working with this agent, a technician in the Henles' laboratory in Philadelphia developed infectious mononucleosis. Her serum, which lacked antibody several months prior to disease, developed EBV antibody during illness, and her lymphocytes, which had previously failed to be cultivated successfully, now grew well in tissue culture and were shown to contain EBV antigen. ${ }^{(72)}$ This serendipitous observation was rapidly confirmed and extended at that time by the Henles in conjunction with Niederman and $\mathrm{McCollum}^{(114)}$ of Yale and later in several other prospective studies carried out by the Yale team $^{(50,113,132)}$ and in one English study. ${ }^{(148)}$ Subsequent investigations established the presence and persistence of EBV in the throat during and after acute infectious mononucleosis, ${ }^{(19,59,103)}$ the occurrence of EBV-specific $\operatorname{IgM},(3,66,114 \mathrm{~b}, 133)$ and the reproduction of some features of mononucleosis by inoculation of EBV into monkeys. ${ }^{(135,154)}$ Fuller details of the history of infectious mononucleosis have been published elsewhere. ${ }^{(16,43)}$

\section{Methodology}

\subsection{Mortality Data}

Infectious mononucleosis is rarely a fatal disease; only about 50 fatalities have been reported. ${ }^{(39)}$ Examination of autopsy records or of international indexes of causes of death would therefore give little indication of the occurrence of the disease even though its pathological features are quite characteristic. 


\subsection{Morbidity Data}

Infectious mononucleosis is not a reportable disease in most states and in most countries. Excentions are the state of Connecticut, where it has been reportable since $1948,{ }^{(21)}$ and the United States armed forces, which collect hospitalization data on all diseases. ${ }^{(41)}$ Unless strong emphasis is placed on the need for fulfilling clinical, hematological, and serological criteria for diagnosis before reporting, the reliability of morbidity data from these sources must be seriously questioned. This requirement is emphasized by the fact that even for the 15-25 age group-in which the disease has its highest incidence, its most characteristic clinical features, and the highest frequency of elevated heterophile antibody tests-only one-third of the serum samples sent to a state laboratory for diagnosis of suspected cases were heterophile antibody positive. ${ }^{(38)}$

To collect morbiaity aata, special surveys of selected populations for infectious mononucleosis have been carried out in college infirmaries, ${ }^{(50,83 a, 113,132)}$ community medical care groups, ${ }^{(69)}$ and general practitioners' offices, ${ }^{(83)}$ and by physicians and laboratories serving defined communities. ${ }^{(29 a, 36,68,131 a)}$ The Center for Disease Control (CDC) also periodically publishes a Surveillance Report on infectious mononucleosis based on data derived from 19 colleges. ${ }^{(18)}$

The problems of data derived from such surveys are related to the extent to which the numerator or case report reflects the proper diagnosis and whether adequate surveillance has been carried out with respect to the denominator-the population at risk.

\subsection{Serological Surveys}

Up to 1968, when the causal association of EBV with infectious mononucleosis was discovered, the heterophile antibody constituted the only serological approach to diagnosis and survey work. Because this is an IgM-type antibody and is transient in nature, it can be used as a serological tool only for incidence data-i.e., during the acute illness-and as an essentral diagnostic feature. ${ }^{(114)}$ The specificity of a properly performed quantitative heterophileantibody test is high provided that the serum has been preabsorbed with guinea pig kidney in the sheep and horse red cell tests or that the beef hemolysin test has been used. In a test performed in this way, an elevated titer quite accurately reflects the occurrence of infectious mononucleosis even in the absence of clinical and hematological data and has been utilized as an indicator of infectious mononucleosis in sera sent to hospitals and state laboratories. ${ }^{(38)}$ The major limitation of this approach is the extent to which physicians have sent sera from suspected cases to the diagnostic laboratory for analysis. The increasing use of simple laboratory kits for identifying heterophile-antibody elevations in the physician's office probably results in much less utilization of state and hospital laboratories, so that morbidity data from these sources may greatly underestimate the occurrence of the disease. Thus, utilization of the heterophile antibody as an epidemiological tool to identify the acute illness has high reliability and specificity but low sensitivity. Heterophile-positive cases diagnosed in the Connecticut State Public Health Laboratory alone represented $74.5 \%$ of all the reported cases in the state in 1972.

Since the discovery of EBV as the cause of infectious mononucleosis in 1968, many serological surveys in different countries have been made for the presence of antibody to this virus in sera collected from healthy persons, usually employing the indirect immunofluorescence test ${ }^{(70)}$ for viral capsid antigen (VCA). This IgG antibody persists for many years, pernaps tor lite. ${ }^{(14,44)}$ These studtes yield prevalence data on prior EBV infection, but give no direct indication of the occurrence of clinical infectious mononucleosis. More recently, the EBV-specific IgM antibody has been included in surveys to identify recent infection. ${ }^{(144 a)}$

The most accurate information on the incidence of both EBV infections and clinical infectious mononucleosis has come from prospective seroepidemiological studies of defined populations with close clinical surveillance for the occurrence of suspected cases of infectious mononucleosis and other illnesses. Sera taken at the start of the observation period are tested to define the number of susceptibles, i.e., those lacking EBV antibody; samples showing seroconversion at the end of the observation period will identify the total EBV infection rate; those collected during interim illnesses and tested for EBV and heterophile antibodies will delineate the number and spectrum of clinical illnesses, such as infectious mononucleosis, associated with EBV infection. 


\subsection{Laboratory Methods}

3.4.1. EBV Isolation. The virus cannot be grown in the usual tissue cultures employed for other herpesviruses. The currently available isolation technique is tedious, difficult, and usually confined to research laboratories. It is based on the ability of EBV to transform uninfected human leukocytes into continuous cell lines and the identification of this effect as due to EBV. ${ }^{(19,103)}$ Leukocytes derived from the cords of newborn infants or from persons lacking EBV antibody are employed to ensure absence of EBV antigen in the lymphocytes. Throat washings or other materials to be tested are usually filtered to remove debris and bacteria, then added to the leukocytes, and placed on a placental fibroblast feeder layer. If EBV is present, evidence of transformation is indicated by an abrupt increase in the total number of cells, the production of acid, growth of cells in clumps, and the development of the capacity to be subcultured indefinitely. Usually, transformation occurs 30-90 days after addition of the throat washing.

The presence of EBV-associated nuclear antigen (EBNA) can be demonstrated in acetone-fixed smears of transformed cord cells using an indirect complement-fixation (CF) fluorescence technique, ${ }^{(129)}$ but VCA cannot be demonstrated by ordinary immunofluorescence methods, presumably because the virus does not mature sufficiently in such cells. EBVtransformed leukocytes may also be grown further in culture to prepare a CF antigen as a means of identification; however, this is a laborious method. More sensitive methods of antigen detection, chemical means of enhancing the rapidity of viral multiplication to shorten the long observation time, or discovery of a more sensitive cell line will be needed before viral isolation will be practical in the diagnostic laboratory. Robinson and Miller $^{(129 a)}$ have demonstrated that DNA stimulation occurs early in EBV-infected cord cells and can be detected by increased uptake of radio-labeled thymidine.

3.4.2. EBV Antibody. A wide variety of techniques to measure EBV antibody have been developed. Five antibody methods based on immunofluorescence have been used. ${ }^{(73 a)}$ First, for epidemiological purposes, the indirect immunofluorescence test of the Henles ${ }^{(70)}$ for VCA has been widely employed in serological surveys as a reliable indicator of susceptibility and immunity to infectious mononucleosis. However, it has not proved very useful as a diagnostic test for infectious mononucleosis because antibody is usually present by the time the patient seeks medical care and rises in titer are detectable in only $15-20 \%$ of cases. Second, antibody to "early antigen" is also identified by immunofluorescence techniques, ${ }^{(74,76)}$ and its presence is indicative of recent or active infection. Unfortunately, from a diagnostic standpoint, it is demonstrable only in about $75 \%$ of patients with infectious mononucleosis ${ }^{(77)}$; it also occurs in the sera from patients with Burkitt lymphoma and nasopharyngeal cancer. Third, antibodies to EBNA are detectable by an immunofluorescence technique based on CF; these usually arise only 1 month or more after onset of infectious mononucleosis and after primary infections and probably persist for life. ${ }^{(73)}$ Their late appearance impairs their usefulness in routine diagnosis. Fourth, there is an indirect immunofluorescence test for EBV-specific IgM antibody, and this is the most useful procedure for the diagnosis of heterophile-negative infectious mononucleo$\operatorname{sis}^{(29,114 b, 133)}$; however, in its present form, this test is technically difficult to perform, and it is not currently available in most diagnostic laboratories. Finally, a membrane fluorescence test has been developed by Klein et al. ${ }^{(88-90)}$ Other antibody tests include CF using either the virus ${ }^{(1)}$ or soluble antigens, ${ }^{(56,57)}$ neutralization tests based on contact inhibition, ${ }^{(78,105)}$ and immunodiffusion tests. ${ }^{(116)}$

3.4.3. Heterophile Antibody Tests. Three general methods are employed: (1) the classic Paul-Bunnell test ${ }^{(121)}$ using sheep or horse red cells after absorption of the serum with guinea pig kidney as developed by Davidsohn and Walker ${ }^{(23)} ;(2)$ the beef-cell hemolysin test of Bailey and Raffel ${ }^{(2)}$ adopted for diagnostic use by Mason, ${ }^{(98)}$ which does not require absorption of sera with guinea pig kidney because beef-cell hemolysins are absent or at very low titers in normal sera; and (3) the enzyme test of Wöllner, ${ }^{(157)}$ in which red-cell receptors for heterophile antibody are specifically removed by treatment with papain or a similar enzyme. Recent evidence suggests that heterophile-antibody titers may reach diagnostic levels even after mild or asymptomatic EBV infections provided serial specimens are tested over a month or so by the horse-cell differential test. ${ }^{(52)}$ The test is also useful in childhood EBV infections, which are often mild. Most state and large diagnostic laboratories employ either the Davidsohn 
differential absorption test or the beef-cell hemolysin test; the former, using horse cells, is more sensitive, and heterophile antibody to this antigen often persists at diagnostic levels for as long as a year or so. ${ }^{(52,93)}$ The beef hemolysin test is more specific but less sensitive, and disappears in 3 months or less; it is perhaps the most reliable test to diagnose infectious mononucleosis during the acute illness. A new immunoadherence test of high sensitivity is also promising. ${ }^{(94 \mathrm{c})}$

A number of commercial testing kits for the diagnosis of infectious mononucleosis in the physician's office are now available. Most are slide agglutination tests, usually performed at a single dilution and commonly based on the agglutination of formalinized horse cells. Some of these employ guinea pig kidney to remove nonspecific agglutinins from the serum prior to testing. Other tests employ papain-treated red cells in the agglutination test. A spot test using horse red cells and absorption procedures is recommended. Such tests are useful if carried out by trained personnel.

\section{Biological Characteristics of the Agent}

\subsection{The Virus}

$\mathrm{EBV}$ is a distinctive member of the herpes group of viruses. On electron microscopy, EBV appears similar to other herpes-group viruses. ${ }^{(33)}$ Currently, two laboratory strains of EBV have been identified, ${ }^{(106)}$ but the sophisticated techniques needed to differentiate strain differences as small as exist between herpes types I and II are not yet available. Definitive evidence of differences in EBV isolates from nature have not yet been found, although minor variations exist. ${ }^{(59 a)}$ The virus has been cultivated only in suspension cultures of primate lymphocytes, and most cultures yield only small amounts of extracellular virus. These limitations have made characterization of the physical and chemical properties of EBV very difficult. EBV is a lymphotropic virus and infects $B$ lymphocytes, which have EBV receptors on their surface ${ }^{(85 a)}$ near to or identical with the $\mathrm{C} 3$ receptors ${ }^{(154)}$; new membrane antigens are induced to which $\mathrm{T}$ cells respond. All lymphocytes in continuous cultures established from infectious mononucleosis blood or Burkitt lymphoma biopsies contain the EBV genome as demonstrated by DNA hybridization or EBNA tests, but only 1-3\% have demonstrable $\operatorname{VCA}^{(115,117,129,160)}$; cell clones grown from such cultures show a similar low percentage of complete virus. ${ }^{(99,159)}$ One line of cells from Burkitt lymphoma, the P3J line of Pulvertaft,, ${ }^{(28)}$ and its cloned derivative, the HR1K, produce more extracellular virus than other lines but fail to induce transformation. ${ }^{(106)}$ Another line, B95-8, derived from EBV-infected marmoset cells by Miller and Lipman, ${ }^{(102)}$ releases about 1000 times more transforming virus but about the same number of viral particles as HR1K. It has been useful in viral characterization. ${ }^{(68 c, d)}$

Some of the biological properties of EBV are important epidemiologically. The capacity for persistence of a lytic infection in the throat provides a source of potential transmission; the low yield of extracellular virus may bear on the need for intimate, oral contact for transmission in young adults. ${ }^{(140)}$ The reasons for the higher efficiency of transmission of EBV infection in young children than in adults are unknown, but might include the production of more infectious virus in the pharynx of children, more intense exposure, or indirect spread by saliva in settings with poor hygiene.

The capacity for persistence and latency of EBV in a nonproductive form sets the stage for later reactivation under conditions of immunosuppression (e.g., malaria, therapeutic immunosuppression in renal transplants). African Burkitt lymphoma and nasopharyngeal cancer may be expressions of this reactivation. The long-term persistence of EBV in lymphocytes is of importance epidemiologically in the transmission of infection during blood transfusions to susceptible recipients. Of great importance is the capacity of EBV to transtorm unintected primate lymphocytes, inducing in them the potential tor unlımited proliferation; this property was termed "immortalization" by Miller, (10u) and the lymphocytes that result are termed "I lymphocytes." The EBV-transformed and -infected cells are B-type lymphocytes. ${ }^{(18,119)}$ Viral induction of new antigens (or unmasking of preexisting ones) such as the membrane antigen of Klein et al. ${ }^{(88)}$ may have immunological consequences in the development of new antibodies, in a graft-vs.-host response, and in the induction of cytotoxic T lymphocytes. ${ }^{83 b, 131 c)}$

A better understanding of the dynamics and effects of EBV activity at molecular and cellular levels ("molecular epidemiology") and of the responses 
of the host of them under varied conditions of age, concomitant infection, immune status, and genetic constitution will be needed before the full spectrum of clinical response is known.

\subsection{Proof of Causation of Infectious Mononucleosis}

The causation of heterophile-positive infectious mononucleosis by EBV has been established beyond any reasonable doubt. The proof is based on seroepidemiological and virological evidence and also on partial success in the experimental transmission of infection to monkeys and man.

Seroepidemiological investigations have repeatedly shown that antibody to EBV of the IgG type has been consistently absent in sera taken prior to the onset of infectious mononucleosis, regularly appears during illness, and persists for years thereafter. ${ }^{(50,65,114,132,148)}$ The presence of this antibody indicates immunity to clinical infectious mononucleosis, and its absence indicates susceptibility to the disease. Table 1 summarizes 11 prospective studies involving over 5000 children and young adults in support of this relationship. No other virus has been found that induces a similar antibody, and no other viral antibody has been demonstrated during heterophile-positive infectious mononucleosis. The occurrence of some heterophile-negative cases of infectious mononucleosis due to EBV has also been noted in prospective studies. ${ }^{(50,65)}$ Other monolike syndromes are due to cytomegalovirus and other agents. $^{(44 a, 92)}$

EBV-specific antibody of the IgM class has been demonstrated during acute infectious mononucleosis and found to disappear during convalescence, thus indicating that this is a primary response to EBV infection. ${ }^{(4,29,66,133)}$ Both the IgG and IgM EBVspecific antibodies of infectious mononucleosis are distinct from the heterophile antibody.

The virological evidence consists of the appearance of EBV in the oropharynx and in the circulating lymphocytes of patients with acute infectious mononucleosis. The agent has been regularly demonstrated in the pharynx of over $80 \%$ of patients during the acute illness ${ }^{(19,59,103,125)}$ and may be multiplying in epithelial cells. ${ }^{(94 a)}$ In addition, EBV antigens have been found in tonsillar lymphocytes. ${ }^{(149 a, b)}$ They persist for many months and in several cases have persisted for as long as a year or so. A chronic carrier state may exist, as suggested by the presence of virus in the oropharynx of $15-20 \%$ of healthy adults. ${ }^{(20,59,143)}$

EBV has been regularly demonstrated in lymphocyte cultures from patients with acute infectious mononucleosis, where it may remain in a latent form for years and may be a source of transfusion mononucleosis. ${ }^{(26,58,75)}$ EBV has now been demonstrated in fresh $\mathrm{B}$ lymphocytes from patients with acute infectious mononucleosis ${ }^{(90 a, 130 a)}$ : up to $0.5 \%$ of circulating mononuclear leukocytes are EBV-infected during the acute illness. ${ }^{(130 a)}$ The appearance and persistence of EBV in the oropharynx following mild or asymptomatic infections provides a large pool of healthy carriers capable of transmitting infection through appropriate exposure.

Efforts to transmit infectious mononucleosis to volunteers using blood, throat washings, or stools from acutely ill patients were made prior to the discovery of EBV in 1968; the results were largely inconclusive or unsuccessful, probably because of the presence of prior immunity in tnose inoculated.

Table 1. Summary of 11 Prospective Studies of Epstein-Barr Virus Infection in Children and Young Adults ${ }^{a}$

\begin{tabular}{|c|c|c|c|c|}
\hline \multirow[b]{2}{*}{$\begin{array}{c}\text { EBV antibody status at } \\
\text { start }\end{array}$} & \multirow[b]{2}{*}{ Number } & \multirow[b]{2}{*}{ Percentage } & \multicolumn{2}{|c|}{ Subsequent rate/100 per year } \\
\hline & & & EBV infection & $\begin{array}{l}\text { Clinical infectious } \\
\text { mononucleosis }\end{array}$ \\
\hline With antibody & 3733 & 70.7 & 0 & 0 \\
\hline Without antibody & 1547 & 29.3 & 16.4 & 7.1 \\
\hline TOTALS: & 5280 & 100 & 4.6 & 2.0 \\
\hline
\end{tabular}

${ }^{a}$ From ten studies carried out by Yale investigators ${ }^{(50,132,148)}$ and one by an English team. ${ }^{(148)}$

${ }^{b}$ Clinical infectious mononucleosis was recognized in $47 \%$ of those infected with EBV. 
However, there are a few exceptions. Wising(156) successfully transmitted the full-blown disease to a female volunteer by transfusion. Evans ${ }^{(37)}$ and Taylor ${ }^{(145)}$ reported suggestive evidence of successful transmission by inoculation of pooled sera from patients with acute infectious mononucleosis into patients with acute leukemia as a therapeutic effort to induce a remission; the young age of this group probably meant that some were susceptible because they had not been previously exposed. About 50 other experiments in humans were equivocal or unsuccessful. ${ }^{(3,34,36,112)}$ Similarly, earlier efforts to induce infectious mononucleosis in monkeys were not rewarding. ${ }^{(49,137)}$

Recent studies with this virus in humans have been very limited because of concern for the oncogenicity of EBV. Grace et al. ${ }^{(61)}$ repeatedly inoculated partially purified EBV into a terminal cancer patient who lacked prior antibody; both EBV and heterophile antibodies developed. Inoculation of EBV-infected lymphocytes into gibbons has resulted in an exudative tonsillitis and the appearance of EBV antibody. ${ }^{(154)}$ Shope and Miller ${ }^{(135)}$ have induced transient EBV and heterophile antibody in squirrel monkeys inoculated with virus-transformed leukocytes. The current evidence of successful transmission of infectious mononucleosis to monkeys must be regarded as incomplete at this time.

In summary, the results of seroepidemiological, virological, and transmission studies in man and monkeys indicate that EBV is the cause of all cases of heterophile-positive mononucleosis and most heterophile-negative cases. ${ }^{(40,42,44 a)}$

\section{Descriptive Epidemiology}

\subsection{Prevalence and Incidence}

The prevalence of antibody to the VCA of EBV has been determined in many countries and in many age groups. ${ }^{(42)}$ Figure 1 indicates the percentage of children in several areas of the world with EBV antibody. In developing and tropical areas, most children have been infected by age 6 years. Because infections with EBV are often mild and asymptomatic in young children, infectious mononucleosis may not be commonly recognized as a clinical entity in such countries. However, more intensive clinical and serological studies, especially employing newer diagnostic techniques, have permitted identification of both heterophile-positive and heterophile-negative cases of infectious mononucleosis in children in such settings as Singapore ${ }^{(12 a)}$ and Brazil. ${ }^{(117 a)}$ The prevalence of EBV antibody in young adults living in different parts of the world is depicted in Fig. 2. A similar socioeconomic pattern exists. It is only when a significant percentage of the population reaches ages 15-25 before exposure to and infection with EBV that infectious mononucleosis emerges as an important clinical entity. This delay in exposure is largely limited to nations with high economic and hygienic levels and to middle and upper socioeconomic classes in any country. The most susceptible college group tested thus far were entering freshman students at Yale University in the period 1958-1963, when nearly $75 \%$ were at risk to infectious mononucleosis because they lacked antibody;
Fig. 1. EBV antibody prevalence at age 4-6 years in different populations. Adapted from Evans. ${ }^{(42)}$

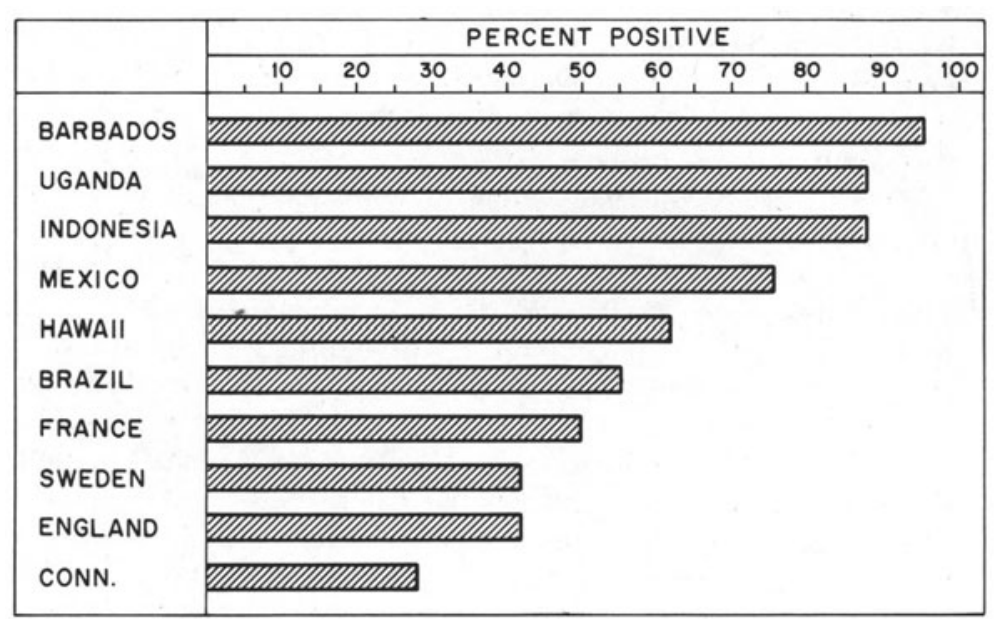




\begin{tabular}{|c|c|c|}
\hline & \multirow{2}{*}{$\begin{array}{l}\text { No. } \\
\text { TESTED }\end{array}$} & PERCENT WITH ANTIBODY \\
\hline & & $\begin{array}{llllllllll}10 & 20 & 30 & 40 & 50 & 60 & 70 & 80 & 90 & 100\end{array}$ \\
\hline \multicolumn{3}{|l|}{ MILITARY RECRUITS } \\
\hline COLOMBIA & 303 & 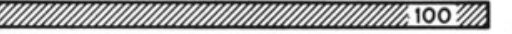 \\
\hline ARGENTINA & 120 & T/1980 \\
\hline UNITED STATES & 484 & WIIA 93 \\
\hline \multicolumn{3}{|l|}{ COLLEGE FRESHMEN } \\
\hline & 145 & 100 \\
\hline PHILIPPINES & 122 & 82 \\
\hline U.S.: WEST POINT & 1401 & 63 \\
\hline U.S: YALE GIRLS ('70) & 139 & 60 \\
\hline ENGLAND: 5 COLLEGES ('70) & 1437 & 57 \\
\hline U.S.: YALE BOYS ('68) & 355 & 51 \\
\hline NEW -ZEALAND ('69) & 50 & 48 \\
\hline U.S: SMITH GIRLS ('60) & 87 & 38 \\
\hline U.S.: YALE BOYS ('58-'63) & 424 & 26 \\
\hline
\end{tabular}

Fig. 2. EBV antibody prevalence in young adults in different populations. $(\times)$ Student nurses. Adapted from Evans. ${ }^{(42)}$

coincident with programs that broadened admission to include students with widely differing socioeconomic backgrounds, among them many minority groups, the susceptibles decreased to $40-50 \%$. In contrast, under $20 \%$ of undergraduate students at the University of Philippines lacked EBV antibody, and all of 145 freshman student nurses in Thailand had antibody.

Hospitalization rates for infectious mononucleosis in the armed forces range from 148 to 250 per $100,000{ }^{(41)}$ In the Navy and Marine Corps, for which comparative data are available, it ranks as the fifth most common infectious disease and the fourth most common cause of days lost.

The incidence of clinical infectious mononucleosis is not well documented, since reporting is not obligatory in most states in the United States, and the available data have usually been derived from special surveys such as the community survey in Atlanta, Georgia, where a rate of 45 per 100,000 of heterophile-positive cases was found, and in Olmstead County, which includes the Mayo Clinic, where resident rates were 200 per 100,000. In Denmark, the rate of notified cases is 60 per 100,000 . $^{(131 a)}$ The state of Connecticut requires reporting of infectious mononucleosis, and rates of 48 per 100,000 were recorded in 1972. ${ }^{(21)}$ In 1979, a simplified report form and an aggressive surveillance system were initiated for all reportable diseases, resulting in a rate for infectious mononucleosis of 137.7 per 100,000 . $^{(21 a)}$ This rate of infectious mononucleosis is surpassed only by chicken pox and gonorrhea among reportable diseases in Connecticut for 1979 and greatly exceeds mumps, rubella, measles, and hepatitis (Table 2). As comparison, the United States rates for these communicable diseases per 100,000 in 1978 were as follows: gonorrhea, 464.7; chicken pox, 80.4; hepatitis A, 13.5; measles, 12.3; primary and secondary syphilis, 10.0; and rubella, 8.4. Among college students, the rates of infectious mononucleosis are very high, averaging 840 per 100,000 students in 19 colleges in 1971-1972. ${ }^{(18)}$

The most accurate measure of EBV infection and of disease has been obtained in prospective serological and clinical studies, where the number of susceptibles, the infection (seroconversior) rate, and the clinical attack rate can be critically defin ed. Comparative data are available from three prospective investigations of freshman students: at Yale University, ${ }^{(132)}$ at five English colleges and universities, ${ }^{(148)}$ and at the U.S. Military Academy at West Point, New York. ${ }^{(65)}$ As depicted in Table 3, the 
Table 2. Reported Cases and Cases per 100,000 Population for Infectious Mononucleosis and Other Reportable Diseases in Connecticut for $1979^{a}$

\begin{tabular}{lrc}
\hline \multicolumn{1}{c}{ Disease } & $\begin{array}{c}\text { Reported } \\
\text { cases }\end{array}$ & Cases/100,000 \\
\hline Chicken pox & 11,525 & 363.0 \\
Gonorrhea & 9,627 & 303.2 \\
Infectious mononucleosis & 4,371 & 137.7 \\
Rubella & 258 & 8.1 \\
Mumps & 231 & 7.3 \\
Hepatitis B & 213 & 6.7 \\
Hepatitis A & 185 & 5.8 \\
Measles & 4 & 0.1 \\
\hline
\end{tabular}

${ }^{a}$ Derived from data provided by the Connecticut State Department of Health.

${ }^{b}$ Based on a population of $3,174,784$.

incidence rate of EBV infection was strikingly similar in all three settings: $12-13 \%$ of susceptible students were infected with EBV during the freshman year, and of those with known EBV infection, 27.7-74.0\% developed clinical infectious mononucleosis. At the U.S. Military Academy, where a prospective investigation was carried on in a single cohort of freshmen over 4 years, the EBV infection rate in susceptible cadets was $12.4 \%$ in the first year, $24.4 \%$ in the second year, $15.1 \%$ in the third year, and $30.8 \%$ in the fourth college year. ${ }^{(65)}$ Over the 4-year period, $45.9 \%$ of susceptible cadets were infected with EBV, and $26.4 \%$ of these were known to have clinical infectious mononucleosis; others may have been ill but not have reported to the clinic for treatment. The reasons for the varying rates of clinical expression among EBV-infected young adults in similar settings are not known. The variation may be related to the intensity of clinical surveillance, the students' attitude toward the health service, the average time of hospitalization, or various host factors. Some ev- idence on the influence of psychological factors is emerging $^{(88 a)}$ (see Section 5.11).

\subsection{Epidemic Behavior}

True epidemics of infectious mononucleosis that fulfill appropriate diagnostic criteria have not occurred in modern times. ${ }^{(38,82)}$ Earlier, many purported epidemics were described, of which the most impressive are those described by West ${ }^{(155)}$ in the United States in 1896, by Moir ${ }^{(107)}$ in the Falkland Islands in 1930, and by Carlson et al. ${ }^{(15)}$ in Wisconsin in 1926. More recent and suggestive outbreaks have been described from an Emergency Medical Hospital $^{(64)}$ and from Oxford, England, reported by Hobson et al. ${ }^{(83)}$ A small outbreak involving 9 of 29 staff members in an outpatient clinic was recently reported by Ginsburg et al. ${ }^{(59 c)}$; however, the source of the outbreak and means of spread were not identified.

The high incidence in military camps during World War II probably reflects the rapid turnover of large numbers of men. ${ }^{(46,149,153)}$ Some reported hospital "outbreaks" are suggestive of a true outbreak, ${ }^{(64,83)}$ but in general do not fully meet diagnostic criteria. On a hypothetical basis, the early acquisition of immunity to infectious mononucleosis by mild and inapparent infections with EBV in childhood and the probable route of transmission via intimate oral contact in young adults weigh heavily against the occurrence of "epidemic infectious mononucleosis."

The high prevalence rates of EBV antibody in children in developing countries, ${ }^{(42,48)}$ in nurseries, ${ }^{(124)}$ and in orphanages ${ }^{(147)}$ suggest that EBV spreads effectively in young children under circumstances of crowding and poor hygiene to reach almost all susceptibles. However, the contagiousness of infectious mononucleosis has been notoriously low in young adult populations; secondary cases have

Table 3. Epstein-Barr Virus Infection Rates during Freshman Year and Percentage Clinically Expressed in Different Colleges

\begin{tabular}{lcccc}
\hline \multicolumn{1}{c}{ Place } & Number in study & Susceptible (\%) & $\begin{array}{c}\text { Infection rate in } \\
\text { susceptibles (\%) }\end{array}$ & $\begin{array}{c}\text { Clinical infectious } \\
\text { mononucleosis (\%) }\end{array}$ \\
\hline U.S. Military Academy $^{(65)}$ & 1401 & 36 & 12.3 & 27.7 \\
Five English schools $^{(148)}$ & 1487 & 43 & 12.0 & 59.1 \\
Yale University(132) $^{(132)}$ & 355 & 49 & 13.1 & 74.0 \\
\hline
\end{tabular}


been rare in roommates of index cases, ${ }^{(37,65,79)}$ in college dormitories, ${ }^{(37,45,132)}$ aboard ship, ${ }^{(122)}$ and on Polaris submarines. ${ }^{(142)}$ The low contagiousness in college populations has been confirmed in recent studies employing the status of EBV antibody as a marker of susceptibility and of infection. Among susceptible and exposed roommates of Yale freshmen with infectious mononucleosis, no evidence of increased risk was found over the susceptible population as a whole ${ }^{(132)}$; however, there tended to be some aggregation of cases in social clusters in dormitories. In a more critical analysis of this issue at the U.S. Military Academy over a period of 4 years, no evidence of increased spread of EBV infection to susceptible roommates exposed to an index case was detected as compared with susceptible roommates not so exposed. ${ }^{(65)}$ In a family setting, about $10 \%$ of exposed and susceptible members will develop EBV infection. ${ }^{(71,85,151)}$

This low level of contagiousness of EBV infection in older children and in young adults of the same sex may be related to a high level of existing immunity and to the need for intimate oral contact. The rate of infection among susceptible persons who are known to have had intimate oral contact with patients who have infectious mononucleosis or with established pharyngeal carriers of EBV has not yet been defined; it may well be high.

\subsection{Geographic Distribution}

Infection with EBV is worldwide. Antibody to EBV has been demonstrated in every population thus far tested, including very isolated tribes in Brazil, $^{(11)}$ Alaska, ${ }^{(147)}$ and other remote areas ${ }^{(57)}$ where measles and influenza antibody are often lacking. Infection occurs earlier in life in developing countries.

Clinical infectious mononucleosis occurs most commonly in those hygienic and socioeconomic areas where exposure to and intection with EBV are delayed until older childhood and young adult life. I his includes Australia, Canada, England, many European countries, New Zealand, Scandinavian countries, and the United States. ${ }^{(42)}$ In contrast, at the University of the Philippines, not a single case was recorded among 5000 admissions to the college infirmary, where laboratory facilities existed ${ }^{(47)}$; EBV antibody determinations in this college population revealed a very high level of prior immunity. The disease is now being recognized with more careful clinical and diagnostic scrutiny in developing countries. ${ }^{(12 a, 117 a)}$ The prevalence of EBV antibody had been found to vary in young adults entering the U.S. Military Academy from different areas of the United States. ${ }^{(65)}$ The highest rate of $81.5 \%$ was found in cadets resident for 6 years or more in the East South Central States and the lowest prevalence rate of $51.9 \%$ in the West North Central States. Since admission to the academy is based on competitive academic, athletic, and achievement values rather than on any social or economic considerations, a broad range of backgrounds would be expected.

\subsection{Temporal Distribution}

There is no clear-cut evidence of yearly fluctuations in the incidence of infectious mononucleosis, although appropriate morbidity data are not available to determine this accurately. Since 1948 in Connecticut, a yearly increase in incidence has been noted from 3.9 cases per 100,000 initially to 46.7 in $1967^{(21)}$; this probably reflects increased reporting rather than actual changes in incidence. In one Swedish hospital where the same population was served and the same diagnostic criteria were presumably applied over a period from 1940 to 1957, the hospitalization rate increased from 12 cases per year in 1940-1942 to 110 per year in 1955-1957. (144) Caution must be observed in interpreting hospital data in which there is no defined denominator. No changes in the incidence rates of infectious mononucleosis were noted at Yale University over a 5year period ${ }^{(50)}$ or in a careful study with a defined population base in Rochester, Minnesota, over the period 1950-1969. ${ }^{(69)}$

Earlier studies of college students at the U.S. Military Academy ${ }^{(82)}$ and at the University of Wisconsin $^{(37)}$ showed a peak in February, some 4-6 weeks after Christmas vacation, presumably due to increased exposure at these times. However, no clear-cut seasonal pattern has been seen in the CDC Surveillance Reports from 19 colleges and universities. ${ }^{(18)}$ In a recent community study in Atlanta, Georgia, ${ }^{(68)}$ two peaks were found, one in early fall and a larger one in later winter and early spring, but in Rochester, Minnesota, ${ }^{(69)}$ no seasonal peak was observed. 
Fig. 3. Acquisition of EBV antibody by age in three different areas. Data derived in part from Evans ${ }^{(42)}$ and Jennings. ${ }^{(84)}$

\subsection{Age}

The acquisition of EBV antibody by age is shown in Fig. 3 for three different geographic areas. Antibody occurs early in life in economically underdeveloped countries, often reaching close to $100 \%$ immunity by age 10 . In a prospective study of EBV infections in newborns living in Accra, Ghana, $81 \%$ had acquired antibody by age 21 months, ${ }^{(10 a)}$ but none showed evidence of clinical infectious mononucleosis. ${ }^{(10 b)}$ In contrast, clinical infectious mononucleosis is clearly a disease of older children and young adults in economically developed countries, with its highest incidence in the 15- to 25-year-old age group. This has been true of data based on hospitalized cases in the United States, $(55,68,69,95,110)$

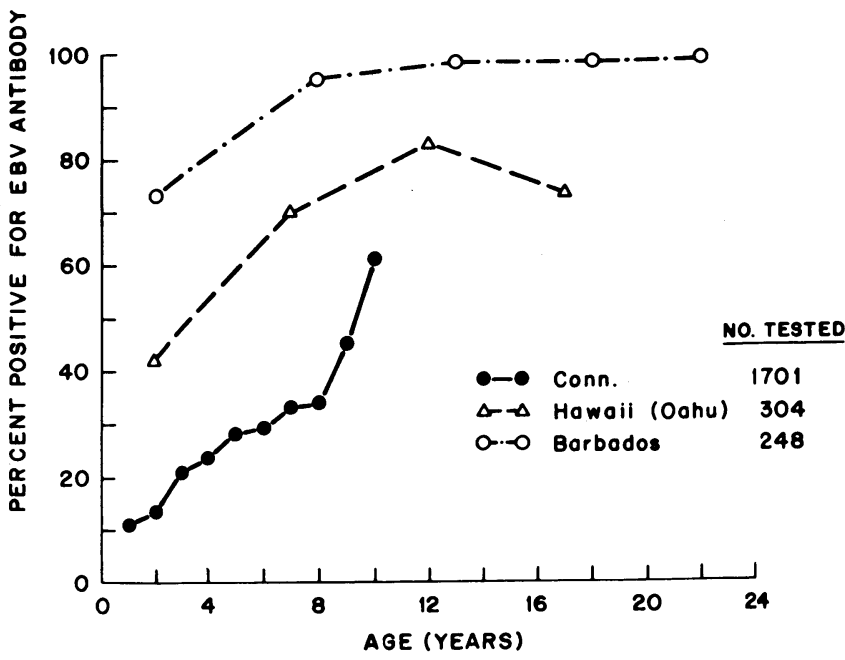

France, ${ }^{(138)}$ and Denmark, ${ }^{(146)}$ on heterophile-positive cases identified in state public-health laboratories, ${ }^{(25,38,108 a, 109,131 a)}$ and on recent community surveys in which the population at risk can be defined. ${ }^{(68,69)}$ In results from the Atlanta community survey based on 575 heterophile-positive cases, the highest rate, 345.2 per 100,000 , occurred in the 15-19 age group and the next highest, 122.8, in the 20-24 age group; 27 heterophile-positive cases occurred in the 5-9 age group, and 4 in the $0-4$ age group. Figure 4 shows the distribution of cases in this study. A similar age distribution was observed in the Wisconsin State laboratory data based on elevated antibody titers in sera from suspected cases sent in for heterophile testing. ${ }^{(38)}$ The peak frequency was in the 20-24 age group, in which $29.6 \%$
Fig. 4. Cases of infectious mononucleosis, by age and sex, metropolitan Atlanta, Georgia, 1968.

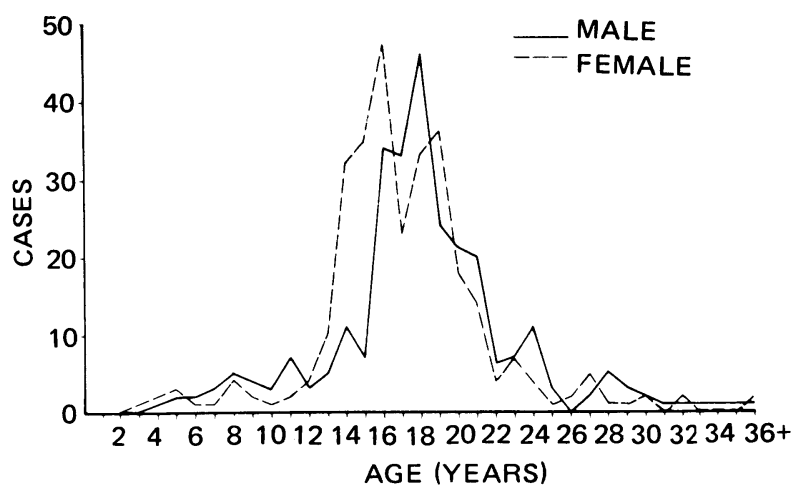


of the sera were positive. Some cases occurred at the extremes of age: $11.9 \%$ of the sera from suspected cases were positive in the 5-9 age group and $5.8 \%$ in the 65-69 age group. Use of more sensitive heterophile tests and of the EBV IgM tests now permits an increasing number of cases to be identified in childhood. ${ }^{(54 a, 59 b, 117 a)}$ The mean age of mononucleosis cases was 18.4 years in Wisconsin ${ }^{(38)}$ and 19.3 years in Norway. ${ }^{(108 a)}$

The age pattern described is that of developed countries. In developing countries, the age distribution will be shifted downward because of the small number of children who escape infection until an age when the host response is that of recognizable infectious mononucleosis. In a recent study in São Paulo, Brazil, the average age of 15 heterophilenegative patients was 4.7 years and that of 31 heterophile-positive cases was 13.2 years. ${ }^{(117 a)}$ The oldest case was age $15 ; 5$ cases occurred in the $0-2$ age group. In this setting, over $90 \%$ of the population has EBV antibody by age $10 .{ }^{(17)}$

\subsection{Sex}

No difference in EBV-antibody prevalence rates by sex have been noted in population surveys.

Infectious mononucleosis occurs equally in both sexes, although girls appear to develop the disease earlier than boys, ${ }^{(68,69)}$ with a peak occurring in girls at age 16 and boys at age 18 (see Fig. 4).

\subsection{Race}

EBV infection occurs in all ethnic groups; no evidence of differential susceptibility has been found.

Infectious mononucleosis in developed countries has been rare in blacks, but this probably reflects socioeconomic levels and earlier acquisition of infection rather than any difference in susceptibility. The incidence of the disease in whites in Atlanta, Georgia, was 30 times higher than in blacks. ${ }^{(68)} \mathrm{An}$ tibody prevalence to EBV among entering black cadets at the U.S. Military Academy was $85 \%$ as compared with $65 \%$ among whites. ${ }^{(65)}$ In an analysis of prevalence rates among different ethnic groups in Hawaii, ${ }^{(84)}$ higher rates were observed in Hawaiians and Filipinos than in Caucasians of the same age. However, socioeconomic levels, hygienic habits, and varying cultural practices in the home cannot be separated from the ethnic backgrounds.

\subsection{Occupation}

Infectious mononucleosis is most often a disease of the college student and of the white-collar worker. ${ }^{(55,110)}$ It is these persons who are likely to escape infection until young adult life because of higher socioeconomic level or hygienic standards or both. It is also common in the military. ${ }^{(30,41)}$

\subsection{Occurrence in Different Settings}

The original cases of Pfeiffer ${ }^{(126)}$ suggested that the disease had a familial pattern, and this has been partially borne out by subsequent studies. Analyses of sera from the Cleveland family study ${ }^{(27,71)}$ produced evidence of several cases in three of seven families. There appeared to be a paucity of EBV infections in the 6-12 year age group in this setting, with higher rates observed in children under 6 and over 12. Among 75 Canadian families, Joncas and Mitnyan ${ }^{(85)}$ identified 67 persons lacking EBV antibody; in follow-up over approximately 2 years, only $10.5 \%$ of these susceptible persons developed EBV antibody. In Sweden, Wahren et al. ${ }^{(151)}$ found EBV antibody increases in 7 of 21 members exposed to an index case; 6 of the 21 contacts lacked EBV antibody initially, and 3 of these seroconverted.

The high rates of infectious mononucleosis in college and military settings have already been noted. However, during the early recruit-training period in the armed forces, infectious mononucleosis is not a common disease, unlike adenovirus, Mycoplasma pneumoniae, and other respiratory infections. This is probably due both to a high level of preexisting immunity among recruits and to the long incubation period of about 4-7 weeks, so that cases usually develop after the end of the usual training period and after dispersal of recruits to other military assignments. The former point is supported by the finding of an antibody prevalence rate of $85 \%$ in entering Marine recruits at Parris Island ${ }^{(94)}$ and of $93 \%$ in Army recruits at Fort Jackson, South Carolina. ${ }^{(51)}$ Among the Marine recruits at Parris Island whose sera lacked antibody, the infection rate was 18.5 per 1000 over the 16 -week training period; in those returning from a 13-month overseas assignment, the EBV infection rate was estimated at 23.8 per 1000. Among the 34 Fort Jackson recruits who lacked EBV antibody, 3 recruits developed EBV antibody during the 16 weeks of basic and advanced training, ${ }^{(51)}$ a rate of 88 per 1000 recruits. 


\subsection{Socioeconomic Factors}

Socioeconomic settings influence the incidence of both EBV infection and infectious mononucleosis, but in opposite directions. Low socioeconomic groups have high rates of EBV infection early in life, but little clinical infectious mononucleosis; high socioeconomic groups have low levels of EBV infection early in life, but a high rate of clinical disease that occurs in the 15- to 25-year-old group. Two examples illustrate this effect on infection rates. At the U.S. Military Academy at West Point, the EBV-antibody prevalence rate was $77.1 \%$ in cadets coming from families earning under $\$ 6000$ and only $58.6 \%$ among those from families with incomes of over $\$ 30,000 .^{(65)}$ In New Haven, the antibody prevalence among first-graders in three schools serving a low socioeconomic group was $84.8 \%$, and in three schools serving a high socioeconomic group, it was $37.8 \%$. ${ }^{(136)}$ A second serum sample collected from these same children 4-5 years later revealed an EBV seroconversion rate of $50 \%$ among susceptible children from lower socioeconomic areas and only $2.4 \%$ in susceptible children in the higher socioeconomic group.

\subsection{Other Factors}

Little is known of the role of nutritional and genetic factors in relation either to EBV infections or to infectious mononucleosis. However, it is recognized that $\mathrm{ABO}$ blood groups are not correlated with susceptibility to infection or to clinical disease. ${ }^{(65,132)}$ The relationship to HLA antigens has not been clearly established. ${ }^{(132 b)}$ It seems likely that genetic control of the immune response plays a role in the severity of clinical illness, in the persistence of virus, and in possible oncogenic sequelae as suggested in recent studies of EBV infections in the X-linked lymphoproliferative syndrome. ${ }^{(128 a, b)}$

Psychological and behavioral factors may influence the frequency with which clinical infectious mononucleosis develops after EBV infection. By correlation of psychological scores taken on entry into the school and subsequent academic achievement with the prospective serological and clinical data collected in cadets at the United States Military Academy at West Point, ${ }^{(65)}$ the following factors were found to be significantly associated with an increased risk of development of clinical infectious mononucleosis in cadets infected with $\mathrm{EBV}^{(88 \mathrm{a})}$ : (1) having fathers who were "overachievers"; (2) having a strong commitment to a military career; (3) ascribing strong values to various aspects of the training and military career; (4) scoring poorly on indices of relative academic performance; and (5) having strong motivation and doing relatively poorly academically. The same factors seemed to influence development of heterophile antibody during mild or inapparent EBV infections, a result free of bias toward seeking medical care.

\section{Mechanism and Route of Transmission}

The major route of transmission of infectious mononucleosis in young adults is probably through intimate oral contact in kissing with the exchange of saliva, as first suggested by Hoagland ${ }^{(79)}$ in 1955. This concept is supported by three types of circumstantial evidence: First, close personal contact without kissing, as in roommates of infected patients ${ }^{(132)}$ or in such confining environments as a destroyer ${ }^{(122)}$ or a Polaris submarine, rarely leads to secondary cases $^{(142)}$; this has been true even when the exposed roommate is known to lack EBV antibody and is followed closely over 2 months for the appearance of antibody or of clinical symptoms. ${ }^{(65)}$ Second, a history of intimate oral contact within the appropriate incubation period is common in young adults who develop infectious mononucleosis ${ }^{(79)}$ and occurs statistically more frequently than in healthy controls or patients with acute respiratory infections. ${ }^{(37)}$ Third, the presence of EBV has been demonstrated in the pharynx during acute illness and during convalescence for periods of many months (Table 4). ${ }^{(19,59,103,114 a)}$ In addition, cross-sectional studies of presumably healthy adults have also shown EBV pharyngeal excretion in 15-20\% of young adults. ${ }^{(59,143)}$ One investigation found a leukocyte-transforming factor, presumably EBV, in the throats of $18 \%$ of 368 patients attending an outpatient clinic. ${ }^{(20)}$ Transmission of EBV infection may also occur via blood transfusions, usually without illness. $(58,75,150)$

This prolonged carrier state after clinical infectious mononucleosis and following inapparent EBV intection may serve as the principal source of exposure in young adults. 'The long duration of virus excretion may explain the difficulties in tracing 
Table 4. Recovery of Epstein-Barr Virus from Oropharyngeal Excretions of 32 Patients with Infectious Mononucleosis

\begin{tabular}{cccc}
\hline & \multicolumn{3}{c}{ Throat washings } \\
\cline { 2 - 4 } Days after onset & $\begin{array}{c}\text { Number } \\
\text { tested }\end{array}$ & \multicolumn{2}{c}{ Positive } \\
\cline { 2 - 4 } \cline { 3 - 4 } $0-6$ & 5 & 1 & 20.0 \\
$7-14$ & 20 & 15 & 75.0 \\
$15-21$ & 8 & 5 & 62.5 \\
$22-28$ & 10 & 6 & 60.0 \\
$29-60$ & 13 & 8 & 61.5 \\
$61-150$ & 12 & 11 & 91.7 \\
$>150$ & 19 & 6 & 31.6 \\
TOTALs: & - & - & -59.7 \\
\hline
\end{tabular}

transmission of disease from case to case. Virus excretion occurs in the presence of circulating antibody, which suggests that humoral antibody does not have a major role in the regulation of oropharyngeal shedding. Clearly, identification of the specific oropharyngeal cells that produce infectious virus remains an important area for further investigation. EBV was not found in the urine of 10 acute cases or in the cervix of 175 pregnant or postpartum women. ${ }^{(149 c)}$

The mechanism of transmission accounting for the rapid and high rate of acquisition of EBV antibody in nurseries and in young children in low socioeconomic circumstances ${ }^{(59 a, 124,147)}$ is not definitely known. Presumably, transfer of infected saliva on fingers, toys, and other inanimate objects in settings of poor hygiene can account for much of the spread of infection. Perhaps more cell-free virus is released in childhood infections. A recent report of hepatitis due to EBV in a hemodialysis unit raises the possibility of airborne spread. ${ }^{(21 b)}$

From a practical standpoint, the low contagiousness of the disease in young adults eliminates the need for strict isolation procedures.

\section{Pathogenesis and Immunity}

The incubation period of infectious mononucleosis is $4-7$ weeks ${ }^{(37,81)}$ in college students. This esti- mate is based on well-defined, often single contacts between an index case and a member of the opposite sex involving intimate oral contact.

Studies of the recovery of EBV from oropharyngeal secretions of patients with infectious mononucleosis have revealed that virus shedding occurs during acute illness and from several weeks to months after onset, but the type of cells involved in viral maturation and release is unknown. Transformation of umbilical-cord leukocytes into continuous cell lines has been the assay system used for demonstration of the virus, and this transformation has been neutralized by sera containing EBV antibody, but not affected by sera lacking this antibody. ${ }^{(103)}$ In addition, transformed leukocytes acquire EBV genome, demonstrated by nucleic acid hybridization, and express EBV-associated antigens. The virus has been detected in throat washings for prolonged periods and as indicated in Table 4 is regularly recovered several months after clinical illness. In 6 of 19 patients, the agent was still present over 5 months after disease had occurred and in 1 case was detected 24 months after onset. No special clinical characteristics have as yet been identified in those cases associated with prolonged oropharyngeal virus shedding.

Prior to the onset of definite symptoms in young adults, there is frequently a history of ill-defined complaints, such as malaise and easy fatigue. It has been suggested that an early, abortive infection of this type may occur in children without subsequent development of classic infectious mononucleosis. ${ }^{(37)}$ In an analysis of 100 presumed heterophile-negative cases of infectious mononucleosis involving the 0-9 year age group studied in England, ${ }^{(83)}$ the incubation period was shorter than for adults and estimated at 4-10 days.

The pathogenesis of infectious mononucleosis is intriguing not only because the self-limited clinical disease is manifested primarily in young adults but also because of the suspected oncogenicity of the virus and its relationship to African Burkitt lymphoma and to nasopharyngeal carcinoma. ${ }^{(32 a)}$ An understanding of what immunological mechanisms turn infectious mononucleosis on and what mechanisms turn it off is important in this context.

Transient depression of delayed hypersensitivity has been described during acute infectious mononucleosis, ${ }^{(10,62)}$ and depressed T-cell stimulation ${ }^{(134)}$ by phytohemagglutinin has been recorded. Re- 
cently, profound alterations in cell-mediated immunity were demonstrated by intradermal skin tests, in vitro lymphocyte stimulation, and enumeration of absolute numbers of peripheral-blood $\mathrm{T}$ and B cells. ${ }^{(97)}$ Lymphocyte responsiveness to a variety of mitogens and antigens was found to be depressed during the first weeks of illness. Serial studies of the interaction of $\mathrm{T}$ - and $\mathrm{B}$-cell populations during acute disease indicated that peripheral-blood $B$ cells increase during the first week of illness and return to normal levels several weeks later. In contrast, $\mathrm{T}$ cells reach peak values during the second week of disease and remain elevated for approximately 5 weeks. ${ }^{(97)}$

Recent investigations indicate that both $\mathrm{T}$ and $\mathrm{B}$ cells may be transformed into atypical lymphocytes characteristic of this disease. ${ }^{(31,60,97,120)}$ These observations suggest that B cells may he trans formed by infection with EBV and T cells transformed as an immunological response to the viral antigen itselt or to altered antigens on the surtace of the B cells,
A schematic diagram of the possible pathogenesis of infectious mononucleosis (Fig. 5) summarizes a hypothetical concept. EBV enters the oropharynx through salivary transfer, probably by kissing in young adults or saliva-contaminated objects in young children. It multiplies locally, presumably in epithelial cells, ${ }^{(94 a)}$ possibly cells of the salivary gland. ${ }^{(94 a, 107 b)}$ A sore throat accompanies this, often with exudative pharyngotonsillitis. A persistent, intermittent oropharyngeal excretion over many years occurs in $15-20 \%$ following either apparent or inapparent EBV infection, ${ }^{(20,114 b)}$ which may be greatly increased during immunosuppression. ${ }^{(143)}$ The local lymphatics are probably invaded, resulting in cervical lymphadenopathy. The virus enters the bloodstream from one of these sources, involves B lymphocytes, and spreads hematologically to the liver, producing hepatitis, and to the spleen, causing splenomegaly; involvement of the brain, lung, or other organs occurs rarely.

EBV has at least three functional effects on B lymphocytes, although it is not known whether sepa-

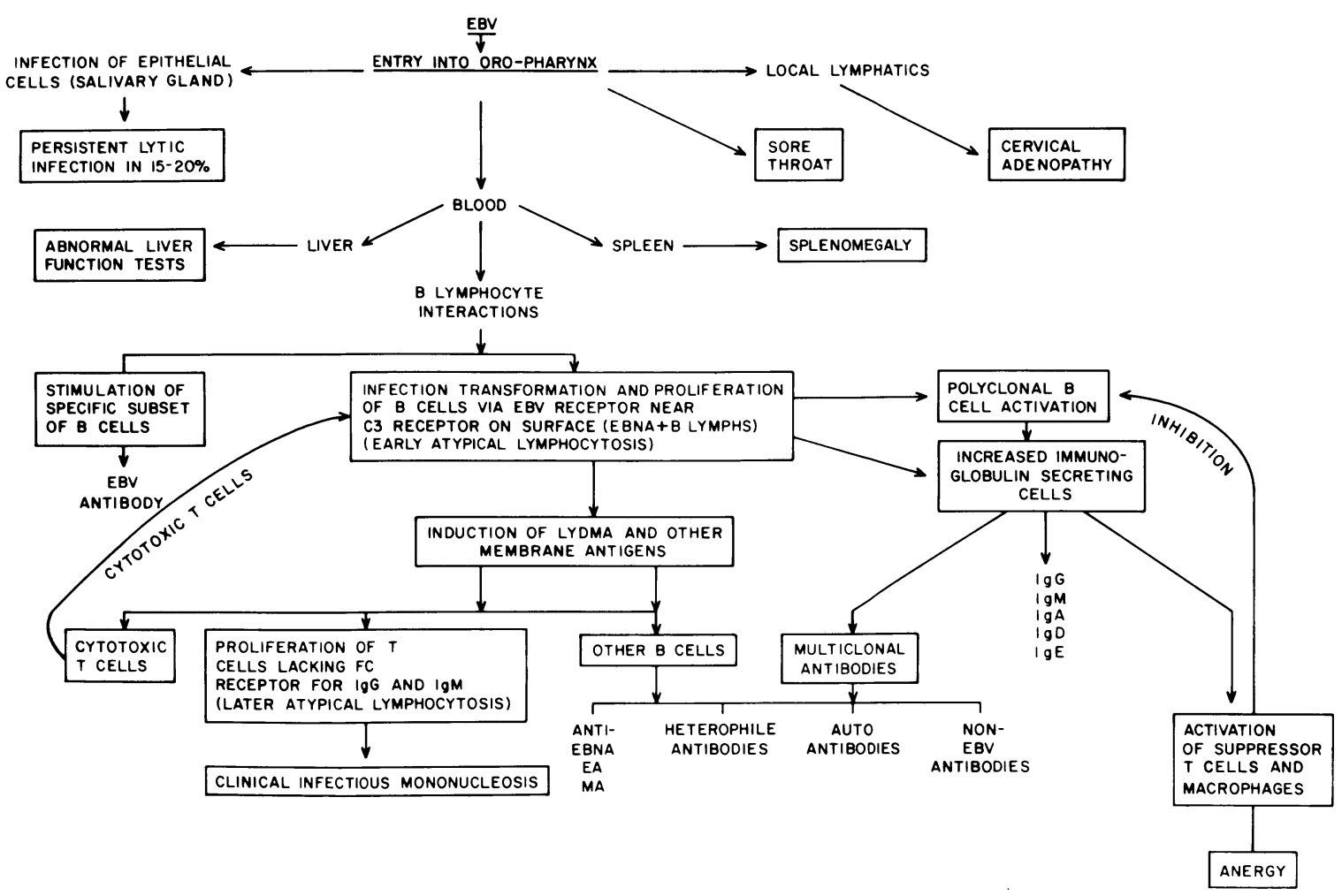

Fig. 5. Hypothetical pathogenesis of EBV infection. 
rate B-cell populations are involved. One is due to the action of virus on a subset of specific antibodyproducing cells, the second results from infection and transformation, and the third is a consequence of polyclonal B-cell activation. The first leads to the production of EBV antibody. The second is a complex event related to the existence of EBV receptors on the surface of $B$ cells near receptors for $C_{3}{ }^{(85 b)}$; the virus enters and multiplies in the $B$ cell, producing EBNA-positive cells and a variety of antigens such as early antigen, VCA, and EBNA, against which specific antibodies are produced via other $B$ cells. The EBNA-positive B cell transforms and proliferates, and this constitutes most of the early atypical lymphocytosis of infectious mononucleosis. ${ }^{(97)}$ In vitro, the transformed B cell is "immortalized"i.e., made capable of continual multiplication. ${ }^{(100 a)}$ EBV induces neoantigens on the surface of some infected B cells, more from adults than children and not in cord cells. ${ }^{(100 a)}$ These antigens include lymphocyte-determined membrane antigen (LDMA) and possibly heterophile antigen of the Paul-Bunnell type, antibodies to which are formed by other $B$ cells. The neoantigens stimulate a B-T cell interaction similar to a graft-vs.-host response, which may account for some of the clinical symptoms of the disease. The mechanism of production of the clinical features of infectious mononucleosis is not well understood, but might result from these B-T cell interactions, from immune complex deposition or other immunopathological events, from direct effects of EBV on cells, or from some combination of these mechanisms. The rarity of classic infectious mononucleosis in early childhood might be related to the failure of EBV to evoke some of these immunological responses, such as induction of neoantigens on the B-cell surface. The $\mathrm{T}$ cells that respond to such neoantigens in older children and young adults represent the atypical lymphocytosis that characterizes the later stages of the acute clinical disease and are composed largely of proliferating $\mathrm{T}$ cells that lack the Fc receptor for IgG and IgM. ${ }^{(68 b)}$ As in other viral infections, some $\mathrm{T}$ cells are cytotoxic and lyse infected cells, $(7,67,83 b, 87,140)$ limiting their proliferation and accounting for the low percentage of EBNA-positive $B$ cells demonstrable in the peripheral blood during the acute disease. ${ }^{(90 a, 130 a)}$ Very early, there may be 15-20\% EBNA-positive B cells, which are reduced early by cytotoxic cells and later by suppressor $\mathrm{T}$ cells to $1-2 \%$ or less. A sufficient number survive, however, to initiate long-term in vitro cultures years later. ${ }^{(32)}$ The third functional effect of EBV on B cells is similar to that of pokeweed mitogen, but is probably due to infection of $B$ cells, rather than a surface effect, and results in a polyclonal B-cell proliferation; an increase in immunoglobulin-secreting cells then occurs, synthesizing IgA early, with $\operatorname{IgD}$, then later IgM and IgG. Multiclonal antibodies are stimulated via other $B$ cells such as sheep-cell antibodies of the Forssman, and possibly of the Paul-Bunnell, type, plus other antibodies unrelated to EBV. ${ }^{(87 a, 147 a)}$ These antibodies are probably not produced directly by EBNA-positive B cells. In the wake of these B-T cell interactions, there appear suppressor $\mathrm{T}$ cells, and perhaps macrophages, which inhibit the proliferation of $B$ cells ${ }^{(68 a, 147 a)}$ and probably underlie the severe anergy that occurs in infectious mononucleosis. To date, EBV-specific suppressor T cells have not been demonstrated, but they may exist.

While the appearance of transformed and proliferating $B$ cells and of cytotoxic and suppressor $T$ cells has been documented, their origin, specificity, interrelationship, and relationship to EBV await clarification. The proliferation of $B$ cells, and the acute disease itself, are limited by cytotoxic $T$ cells, suppressor cells, and humoral antibody. The development of specific cell-mediated immunity to EBV during infectious mononucleosis has been demonstrated. ${ }^{(114 b)}$ A failure of these immune mechanisms, either on a genetic basis, as in the X-linked lymphoproliferative syndrome of males, ${ }^{(128 a, b)}$ or due to acquired immunodeficiencies, as possible in a fatal case in a 4-year-old girl, ${ }^{(129 b)}$ can permit uncontrolled B-cell proliferation, leading to an immunoblastic B-cell sarcoma or to other lymphoproliferative responses (Burkitt lymphoma, ?Hodgkins disease). Such severe, often fatal, oncogenic and sometimes lytic consequences of EBV infection are of great importance in terms of both human life and an understanding of their pathogenesis. A registry has been set up in Massachusetts to record and study them. ${ }^{(65 a)}$

The mechanism of heterophile-antibody production is still unexplained, as is the source of the antigen that produces it, but knowledge that its appearance is most common in EBV infections of young adults ${ }^{(42)}$ and that the degree of expression and release of EBV in vitro varies in lymphocytes from donors of different ages suggests avenues of 
investigation. For example, EBV-infected fetal lymphocytes do not have demonstrable VCA, but do contain EBNA by the EBNA test ${ }^{(101,129)}$ and CF antigen. ${ }^{(101,104)}$ In lymphocytes from adults and from marmosets, EBV may mature more fully, resulting in release of EBV antigens to other lymphocytes. Heterophile antibody may occur in response to membrane-induced antigens of EBV expressing themselves more fully in lymphocytes of young adults than in those of younger children or in fetal lymphocytes. There is preliminary evidence of heterophile-antibody production by lymphocytes cultured from acute cases of infectious mononucleo$\mathrm{sis}^{(107 a)}$ and the various possible mechanisms of its appearance have been reviewed by Kano and Milgrom. ${ }^{(87 a)}$

While the presence of antibody to the VCA of EBV has been shown to indicate protection against infectious mononucleosis and its absence indicates susceptibility, $(44,50,65,113,132)$ the actual antibody that provides immunity is probably the neutralizing antibody for which tests have recently been developed. ${ }^{(78,105)}$ One attack of infectious mononucleosis confers a high degree of durable immunity to subsequent attacks of clinical infectious mononucleosis. ${ }^{(16,50,105)}$ Presumably, subclinical or inapparent EBV infections also confer lasting immunity. One fairly well-documented case of clinical recurrence has been reported ${ }^{(9)}$ and a resurgent anamnestic heterophile response after infectious mononucleosis has also been noted in patients who subsequently develop a respiratory infection. ${ }^{(8,80)}$ Reinfection with or without clinical illness has not yet been fully documented by appropriate heterophile and EBV antibody tests, but asymptomatic endogenous reactivation was found in $32 \%$ of renal-transplant recipients. ${ }^{(1 a)}$

\section{Patterns of Host Response}

\subsection{Clinical Features}

When infection with EBV occurs in childhood, a mild, nonspecific illness or an inapparent infection may develop, both of which are associated with the appearance and persistence of antibody to EBV. If exposure and primary infection are delayed until adolescence or young adulthood, the characteristic clinical picture usually occurs. This consists of fever, pharyngitis, and cervical lvmphadenopathy, accompanied by splenomegaly in $50 \%$ and hepatomegaly in $10 \%$. The pharyngitis is often associated with a whitish or a gray-green exudate having an offensive odor. The eyelids may be swollen, and petechiae occur on the hard palate in $25 \%$ of cases.

Abnormalities of liver-function tests are a regular feature of infectious mononucleosis, and clinically recognizable jaundice occurs in 5\% of cases. Rare manifestations include a variety of central nervous system syndromes (encephalitis, meningoencephalitis, Guillain-Barré syndrome), pneumonitis and pneumonia, thrombocytopenic purpura, mycarditis, and nephritis. ${ }^{(39,82)}$ Hepatitis and central nervous system involvement may occur in the absence of other features of infectious mononucleosis. ${ }^{(29 a, 61 a)}$ The major complications include splenic rupture and airway obstruction from exudative pharyngotonsillitis. About 50 deaths have been reported due mostly to central respiratory failure; recently, cell-associated EBV was detected in the cerebrospinal fluid of a case with complicating meningoencephalitis. ${ }^{(132 a)}$ An immunological deficit, especially in cell-mediated immunity, may influence the severity of the clinical response, as suggested by the report of two deaths in a family ${ }^{(5)}$ and a recent severe illness in a women with a T-cell defect. ${ }^{(136 a)}$ An X-linked recessive lymphoproliferative syndrome in which EBV has been implicated has also been described by Purtilo et al. ${ }^{(128 a, b)}$ Both lytic and proliferative manifestations have appeared in one kindred. These include fatal infectious mononucleosis, malignant lymphoma, and agammaglobulinemia.

The frequency with which EBV infections are expressed as clinical illness in young adults has varied in airterent populations. In a stuay or a conort of U.S. Military Academy cadets over a 4-year period, only $26.4 \%$ of 201 infected with this agent developed heterophile-positive clinical infectious mononucleosis. ${ }^{(65)}$ The apparent : inapparent EBV infection ratio in different years ranged from $1: 1$ to $1: 2.6$ in this population. Comparison of the frequency of clinically expressed infectious mononucleosis in freshman students in three different settings is presented in Table 3 (Section 5.1). As mentioned, the reasons for the differences are not known, by may relate to the motivation to seek medical care, physical fitness, psychological factors, or concern about the effect of hospitalization on academic and school activities. 
The relationships between clinical features and antibody levels in a typical heterophile-positive case in an 18-year-old student are shown in Fig. 6. Following a prodromal period associated with fatigue, fever, and headache over several days, the onset of sore throat, cervical adenopathy, and recurrent fever developed during the second week. Characteristic blood changes were present on the 3rd day after onset, and on culture the patient's lymphocytes contained EBNA CF antigens in a nuclear location. The heterophile-antibody titer was negative on the first day of symptoms, rose to $1: 14$ after guinea pig absorption 2 days later, and then increased to $1: 896$ on the 15th day. In contrast, Epstein-Barr VCA antibodies of IgG type, undetectable on the 3rd day of illness, were present on the 8 th day and rose to a level of $1: 320$ by the 2 nd week. EBV-specific IgM antibodies were demonstrable on the 8 th day at a titer of $1: 2.5$, which then increased to $1: 10$ by the 15 th day.

No direct correlation has been found between the levels of Epstein-Barr VCA and heterophile antibodies or between VCA, early antigen, and EBNA antibody levels and the severity of clinical symptoms and hematological changes. ${ }^{(73,77,114)}$ Neither does their persistence correlate with the duration of clinical illness.

\subsection{Diagnosis}

The diagnosis of infectious mononucleosis is based on a typical clinical picture with the triad of fever, sore throat, and cervical lymphadenopathy, the occurrence of at least $50 \%$ lymphocytosis with at least $10 \%$ atypical lymphocytes, and the appearance of heterophil antibodies. The presence of IgM or early antigen antibodies to EBV, or both, is an absolute requirement in doubtful or heterophilenegative cases. Antibody to VCA is usually present at the time the physician first sees the patient, and only $15-20 \%$ of patients will show a subsequent rise in titer; antibodies to early antigen appear later, but are present in only $75 \%$ of typical cases. ${ }^{(77)}$ Antibodies to EBNA usually arise 1 month or more after illness and probably persist for life. ${ }^{(73)} \mathrm{EBV}$-specific IgM antibodies are demonstrable in $85 \%$ of cases during acute illness. Figure 7 depicts the course of EBV-specific IgG and IgM antibodies during the course of illness. IgG antibodies persist for years, perhaps for life; IgM antibodies usually disappear in 3-6 months. At present, the EBV-VCA-IgM is the best antibody test for diagnosis in cases that are heterophile-antibody negative ${ }^{(29,52,59 b, 114 \mathrm{c})}$; the presence of false positives due to rheumatoid factor must be excluded.

The main reliance in diagnosis must be placed on the hêterophile antibodies, which are of the $\operatorname{IgM}$ type. Metnods in most common use are the sheepand horse-cell agglutination tests after absorption of the serum with guinea pig kidney to remove Forssman antibody, and the beef-cell hemolysin test, which does not require absorption. The appearance and persistence of these tests during acute

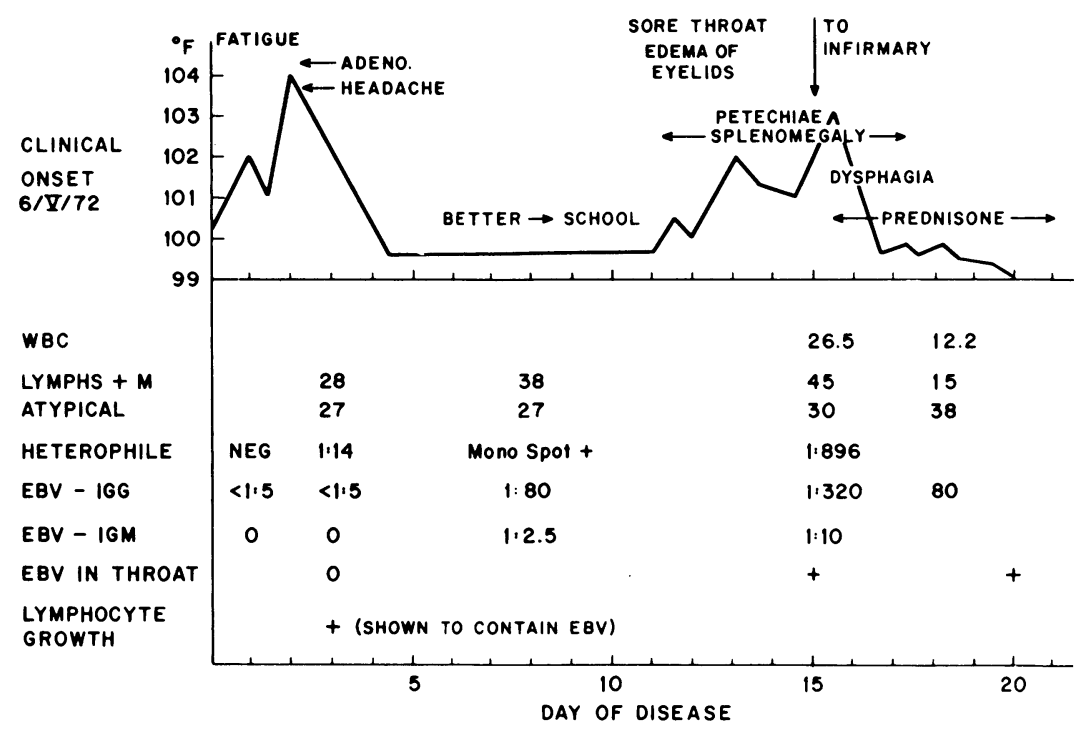

Fig. 6. Relationship between clinical and laboratory features of infectious mononucleosis in an 18year-old male. 
Fig. 7. Appearance and duration of IgG and IgM antibodies specific for EBV during infectious mononucleosis. From Evans et al. ${ }^{(52)}$

and convalescent infectious mononucleosis are shown in Fig. 8. The beef hemolysin test is the most specific but has a short duration; the horse-cell test is the most sensitive and most persistent, with positive tests present for a year or more in $75 \% .^{(52)}$ The ap-

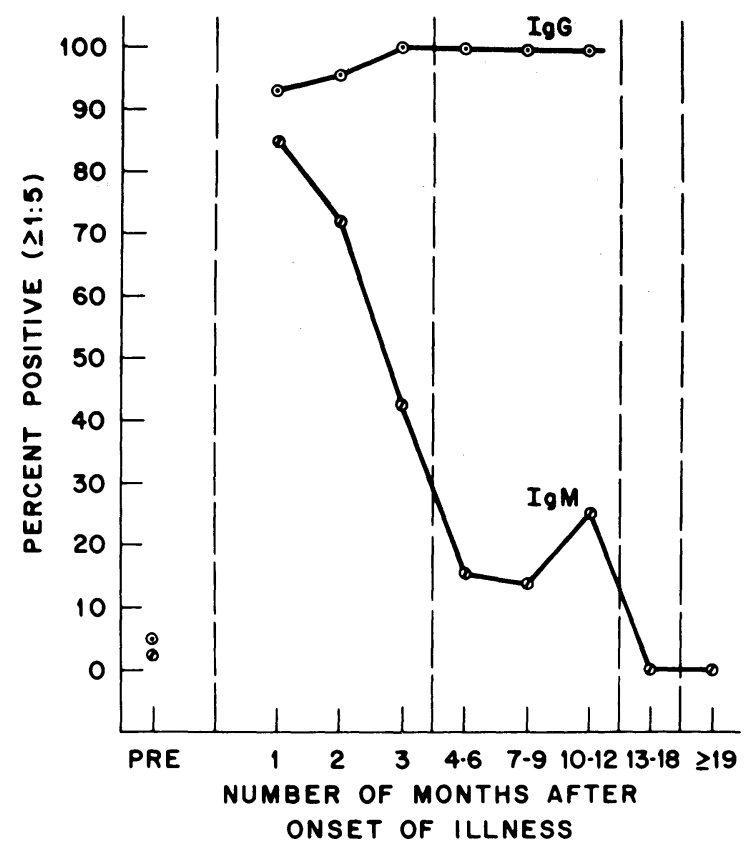

pearance and persistence of antibody to horse cells have been found to follow mild and subclinical episodes of infectious mononucleosis provided that sera are collected over a long enough time. This test is useful in childhood infections with EBV, which

Fig. 8. Persistence of heterophile antibodies during infectious mononucleosis. (RBC) Red blood cells. From Evans et al. ${ }^{(52)}$

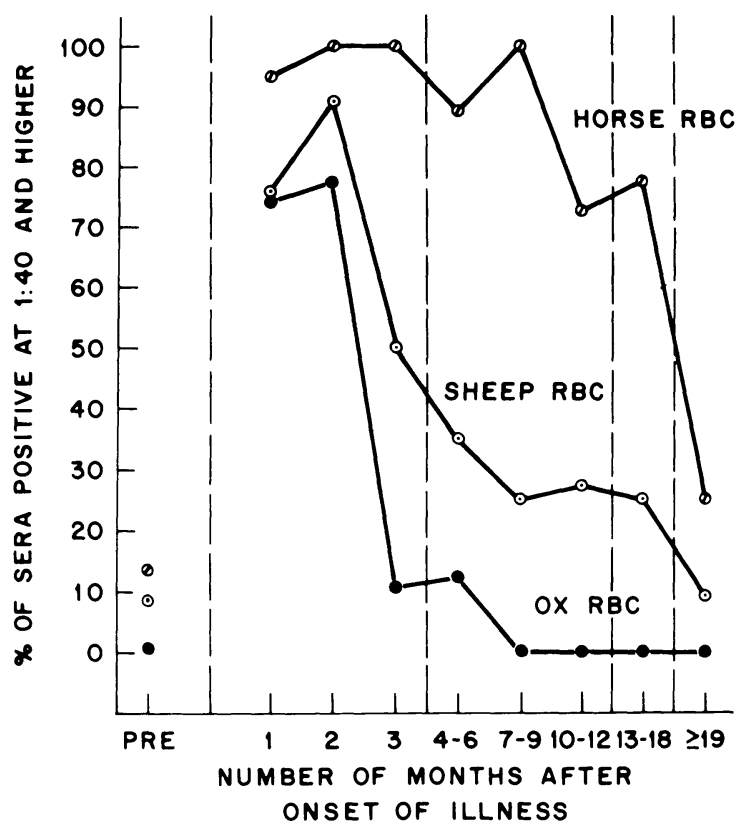


are often heterophile-negative by other tests or when inadequately followed. A new immune adherance heterophile test may also be very useful in childhood infections. ${ }^{(54 a, 94 c)}$

Development of EBV antibody has also been shown in cases where the clinical and hematological characteristics are those of infectious mononucleosis but the heterophile antibody remains persistently negative. ${ }^{(50,114 b)}$ These heterophile-negative, EBVantibody-positive cases appear to be common in infants and children, but are rare in adults. (1va,b, sya) Infection with cytomegalovirus (CMV) may produce a clinical picture of heterophile-negative mononucleosis that is hard to distinguish from classic infectious mononucleosis; however, it usuallv occurs at a later age, and adenopathy and exudative pharyngitis are rare. ${ }^{(91)}$ EBV may possibly be reactivated during the course of other herpesvirus infections, especially CMV. ${ }^{(94 b)}$ Infection with EBV can result in development of a false-positive CMV-IgM-antibody response; however, the reverse does not occur. Toxoplasma gondii, adenovirus, rubella, and hepatitis A infections may also resemble heterophile-negative infectious mononucleosis, but the lymphocytosis is relative and not absolute. The infectious-mononucleosis-like syndromes have recently been reviewed. ${ }^{(44 a)}$

\section{Control and Prevention}

Attempts to control infectious mononucleosis and EBV infections by interrupting the presumed chain of transmission in young adults seem neither realistic nor perhaps desirable in light of our current knowledge. If salivary exchange represents the major route of spread, there seems little likelihood of interdicting this practice. If poor hygienic conditions promote the spread of EBV infections in young children, then improvement in hygienic and socioeconomic circumstances might reduce their incidence. Unfortunately, control of spread at this time when infection is largely mild and asymptomatic might simply delay exposure to later childhood and young adult life when the majority of EBV infections are expressed as clinical infectious mononucleosis.

The high degree of protection against infectious mononucleosis provided by natural infection with EBV suggests that a vaccine capable of evoking sim- ilar humoral, cell-mediated, and local immunity might be highly effective. An attenuated live vaccine administered orally would be the most desirable. However, the apparent limitation of viral multiplication in vitro to primate lymphocyte suspension cultures and the low yield of infectious virus released are formidable technical obstacles at present. Work on EBV-membrane antigens is under way to circumvent some of these problems. ${ }^{(123,128 c)}$

If an effective vaccine were available, it might best be given on entrance to high school to permit natural infection with little clinical illness to occur before that and then to prevent clinical illness in the young adult. It would be useful only in developed countries with a high incidence of infectious mononucleosis.

The oncogenic and transforming potential of F.BV poses a serious question of risk for use of a vaccine. The numerous problems associated with long-term surveillance for possible complications would be considerable, but these risks in developed countries may not be great. The association between EBV and cancer is evident primarily in Burkitt lymphoma in Africa and in nasopharyngeal carcinoma (NPC) patients of Chinese descent in the Far East. In these settings, clinical infectious mononucleosis is too rare a disease to merit vaccination. Furthermore, tumor development is associated with malaria in African Burkitt lymphoma and immunogenetic susceptibility to NPC in Chinese. In the absence of malaria and genetic susceptibility, as in the United States, both these tumors are very rare. Such considerations suggest that if the technical problems of viral attenuation and vaccine production can be overcome, oncogenicity would be a hazard of negligible magnitude in the United States and other countries where clinical infectious mononucleosis is a common and disabling disease.

\section{Unsolved Problems}

The problems that remained to be solved concerning the nature of EBV infections are summarized in Table 5. While EBV is well established as the cause of heterophile-positive infectious mononucleosis and "turns on" the immunological events that are involved in the pathogenesis of the clinical disease, we need more information as to what 
Table 5. Unsolved Questions Concerning Epstein-Barr Virus

1. What turns infectious mononucleosis off and makes it a self-limited disease?

2. What cell supports pharyngeal multiplication of EBV?

3. What is the route of transmission in young children?

4. Where does heterophile antibody originate?

5. Can the EBV-IgM-antibody test be simplified for routine diagnostic use?

6. What causes different responses to EBV at different ages?

7. Is an infectious mononucleosis vaccine possible?

8. Does EBV cause cancer?

9. Why are EBV antibody titers high in some chronic diseases?

10. What accounts for the geographic distribution of Burkitt lymphoma and nasopharyngeal cancer?

"turns off' the lymphoproliferative cycle and makes the disease a benign, self-limited one.

The persistence of EBV in circulating lymphocytes following infection and the presence of a small number of "atypical lymphocytes" in healthy persons suggest that the proliferative process is not fully "turned off" but held under careful control and immunological surveillance; the continued presence of anti-VCA, anti-EBNA, CF, and other viral antibodies supports the concept of continued antigenic stimulation. Viral excretion in the pharynx certainly continues long after infection, perhaps intermittently for life, but the cells supporting this multiplication are at present unknown. The source of heterophile antibody and of the variety of other nonviral antibodies that appear during the course of infectious mononucleosis remains a mystery; whether these antibodies appear in milder EBV infections in smaller amounts and at a later time is not known, but recent evidence suggests this may be so. A simple EBV-IgM antibody test is needed in the diagnostic laboratory to confirm presumably heterophile-negative cases. An explanation is lacking for the observation that a more severe clinical response to EBV infection occurs when exposure is delayed until later childhood and young adult life, similar to the more frequent occurrence of jaundice in hepatitis and paralysis in poliomyelitis infections in adults. If the clinical syndrome of infectious mononucleosis is primarily an immunological response of T cells to EBV-induced neoantigens on the B-cell membrane, then one can speculate that induction of membrane antigens occurs more commonly in lymphocytes from mature persons in whom more complete virus is formed than in lymphocytes from young children; this idea is supported by the failure of EBV-infected cord cells to produce VCA or mem- brane antigens. The possibility of a vaccine has already been discussed, and the relationship of EBV to cancer is explored in other chapters of this book. Infectious mononucleosis continues to be an important model for studying the immunological and virological events involved in a persistent and possibly neoplastic infection.

\section{References}

1. Armstrong, D., Henle, G., and Henle, W., Complement-fixation tests with cell lines derived from Burkitt's lymphoma and acute leukemias, J. Bacteriol. 91:1257-1262 (1966).

1a. Armstrong, J. A., Evans, A. S., RaO, N., and Ho, M., Viral infections in renal transplant recipients, Infect. Immun. 14:970-975 (1976).

2. BAILEY, G. H., AND RAFFEL, S., Hemolytic antibodies for sheep and ox erythrocytes in infectious mononucleosis, J. Clin. Invest. 14:228-244 (1935).

3. Banatvala, J. E., Best, J. M., AND Waller, D. K., Epstein-Barr virus-specific IgM in infectious mononucleosis, Burkitt lymphoma, and nasopharyngeal carcinoma, Lancet 1:1205-1208 (1972).

4. BANG, J., Forsoeg paa at overfoere mononucleosis infectiosa til mennesket, Ugeshkr. Laeg. 105:499-504 (1943).

5. Bar, R. S., DeLor, J., Clausen, K. P., Hurtubise, P., Henle, W., and Hewetson, J. F., Fatal infectious mononucleosis in a family, N. Engl. J. Med. 290:363-367 (1974).

6. BARONDESS, J. A., AND ERLE, H., Serum alkaline phosphatase activity in hepatitis of infectious mononucleosis, Am. J. Med. 29:43-54 (1960).

7. Bauscher, J. C., and Smith, R. T., Studies of Epstein-Barr virus-host-relationship: Autochthonous and allogeneic lymphocyte stimulation by lymphoblast cell lines in mixed cell culture, Clin. Immunol. Immunopathol. 1:270-281 (1973). 
8. BENDER, C. E., Interpretation of hematologic and serologic findings in the diagnosis of infectious mononucleosis, Ann. Intern. Med. 49:852-865 (1958).

9. Bender, E. C., Recurrent mononucleosis, J. Am. Med. Assoc. 182:954-956 (1962).

10. Bentzon, J. W., The effect of certain infectious diseases on tuberculin allergy, Tubercle 34:34-41 (1953).

10a. Biggar, R. J., Henle, W., Fleischer, G., Böcker, J., LenNette, E. T., AND Henle, G., Primary Epstein-Barr virus infections in African infants. I. Decline of maternal antibodies and time of infection, Int. J. Cancer 22:239-243 (1978).

10b. Biggar, R. J., Henle, G., Böcker, J., Lennette, E. T., Fleischer, G., and Henle, W., Primary Epstein-Barr virus infections in African infants. II. Clinical and serological observations during seroconversion, Int. J. Cancer 22:244-250 (1978).

11. Black, F. L., Hierholzer, W. J., Pinheiro, DeP., Evans, A. S., Woodall, J. P., Opton, E. M., EMMONS, J. E., West, B. S., EDSAll, G., DOWNS, W. G., AND WALLACE, G. D., Evidence for persistence of infectious agents in isolated human populations, Am. J. Epidemiol. 100:230-250 (1974).

12. Bloedorn, W. A., And Houghton, J. E., The occurrence of abnormal leucocytes in the blood in acute infections, Arch. Intern. Med. 27:315-325 (1921).

12a. Boon, W. H., MuI, C. L. Y., AND Too, M., Infectious mononucleosis in Singapore, J. Singapore Pediatr. Soc. 19:153-161 (1977).

13. Brown, J. W., Clifford, J. E., Sims, J. L., AND White, E., Liver function during infectious mononucleosis, Am. J. Med. 6:321-328 (1949).

14. Савот, R. C., The lymphocytosis of infection, Am. J. Med. Sci. 145:335-339 (1913).

15. Carlson, G. W., Brooks, E. H., and Marshall, V. F., Acute glandular fever: Recent epidemic, report of cases, Wis. Med. J. 25:176-178 (1926).

16. Carter, R. L., and Penman, H. G., The early history of infectious mononucleosis and its relation to "glandular fever," in: Infectious Mononucleosis (R. L. CARTER and H. G. Penman, eds.), Blackwell, Oxford, 1969.

17. Carvalho, R. P. S., Evans, A. S., Frost, P., DalLDORF, G., CAMARGo, M. E., AND JARMa, M., EBV infection in Brazil. I. Occurrence in normal persons, in lymphomas and in leukemias, Int. J. Cancer 11:191-201 (1973).

18. Center for Disease Control, Infectious Mononucleosis Surveillance, November 1972.

19. Chang, R. S., AND Golden, H. D., Transformation of human leucocytes by throat washings from infectious mononucleosis patients, Nature (London) 234:359-360 (1971).

20. Chang, R. S., Lewis, J. P., and Abildgaard, C. F., Excretors of leucocyte-transforming agents among a human population, N. Engl. J. Med. 289:1328-1329 (1973).

21. Christine, B. W., Infectious mononucleosis, Conn. Health Bull. 82:115-119 (1968).

21a. Connecticut State Health Department, Personal communication.

21b. Corey, L., Stamm, W. E., Feorino, P. M., Bryan, J. A., Weseley, S., GregG, M. B., and Solangi, K., $\mathrm{HB}_{\mathrm{s}}$ AG-negative hepatitis in a hemodialysis unit: Relation to Epstein-Barr virus, N. Engl. J. Med. 293:1273-1278 (1975).

22. Cross, J. G., Conditions simulating an acute leukemia (acute benign leukemia), Minn. Med. 5:579-581 (1922).

23. DAVIDSOHN, I., AND WALKER, P. H., The nature of the heterophilic antibodies in infectious mononucleosis, Am. J. Clin. Pathol. 5:455-465 (1935).

24. Davidsohn, I., Heterophile antibodies in serum sickness, J. Immunol. 16:259-273 (1929).

25. Davidsohn, R. J. L., A survey of infectious mononucleosis in the North-East Regional Hospital Board area of Scotland, 1960-9, J. Hyg. 68:393-400 (1970).

26. Diehl, V., Henle, G., Henle, W., and Kohn, G., Demonstration of a herpes group virus in cultures of peripheral leukocytes from patients with infectious mononucleosis, J. Virol. 2:663-669 (1968).

27. Dingle, J. H., BADGER, G. F., AND JoRdAN, W. S., JR., Illness in the Home: A Study of 25,000 Illnesses in a Group of Cleveland Families, The Press of Western Reserve, Cleveland, 1964.

28. Downey, H., and McKinlay, C. A., Acute lymphadenosis compared with acute lymphatic leukemia, Arch. Intern. Med. 32:82-112 (1923).

29. Edwards, J. M. B., ANd MCSwiggan, D. A., Studies on the diagnostic value of an immunofluorescence test for EB virus specific IgM, Clin. Pathol. 27:647-651 (1974).

29a. Edwards, J. M. B., Vandervelde, E. M., Cohen, B. J., AND MCSwigGan, D. A., Laboratory diagnosis of EB virus infection in some cases presenting as hepatitis, J. Clin. Pathol. 31:179-182 (1978).

30. Ellenbogen, C., and Reinarz, J. A., The Epstein-Barr virus and its relationship to infectious mononucleosis in air force recruits, Mil. Med. 140:371-373 (1974).

31. EnberG, R. N., Eberle, B. J., and Williams, R. C., Peripheral blood $\mathrm{T}$ and $\mathrm{B}$ cells in infectious mononucleosis, J. Infect. Dis. 130:104-111 (1974).

32. Epstein, M. A., AND ACHONG, B. G., Various forms of Epstein-Barr virus infection in man: Established facts and a general concept, Lancet 2:836-839 (1973).

32a. Epstein, M. A., AND ACHONG, B. G., Pathogenesis of infectious mononucleosis, Lancet 2:1270-1278 (1977).

33. Epstein, M. A., Achong, B. G., ANd Barr, Y. M., 
Virus particles in cultured lymphoblasts from Burkitt's lymphoma, Lancet 1:702-703 (1964).

34. Evans, A. S., Experimental attempts to transmit infectious mononucleosis to man, Yale J. Biol. Med. 20:19-26 (1947).

35. Evans, A. S., Liver function tests in infectious mononucleosis, J. Clin. Invest. 27:106-110 (1948).

36. Evans, A. S., Further experimental attempts to transmit infectious mononucleosis to man, J. Clin. Invest. 29:508-512 (1950).

37. Evans, A. S., Infectious mononucleosis in University of Wisconsin students: Report of a five-year investigation, Am. J. Hyg. 71:342-362 (1960).

38. Evans, A. S., Infectious mononucleosis: Observations from a public health laboratory, Yale J. Biol. Med. 34:261-276 (1961/1962).

39. Evans, A. S., Complications of infectious mononucleosis: Recognition and management, Hosp. Med. 3:24-25, 28-33 (1967).

40. Evans, A. S., Infectious mononucleosis: Recent developments, Gen. Pract. 60:127-134 (1969).

41. Evans, A. S. Infectious mononucleosis in the armed forces, Mil. Med. 135:300-304 (1970).

42. Evans, A. S., New discoveries in infectious mononucleosis, Mod. Med. 1:18-24 (1974).

43. Evans, A. S., The history of infectious mononucleosis, Am. J. Med. Sci. 267:189-195 (1974).

44. Evans, A. S., Commentary-EB virus, infectious mononucleosis and cancer: The closing of the web, Yale J. Biol. Med. 47:113-122 (1974).

44a. Evans, A. S., Infectious mononucleosis and related syndromes, Am. J. Med. Sci. 276:325-339 (1978).

45. Evans, A. S., and Robinton, E. D., An epidemiologic study of infectious mononucleosis in a New England college, N. Engl. J. Med. 242:492-496 (1950).

46. Evans, A. S., and Paul, J. R., Infectious mononucleosis, in: Preventive Medicine in World War II, Vol. V: Communicable Diseases (J. B. CoATEs, JR., ed.), Office of the Surgeon General, Department of the Army, Washington, D.C., 1960.

47. Evans, A. S., ANd Campos, L. E., Acute respiratory diseases in students at the University of the Philippines, Bull. WHO 45:103-112 (1971).

48. Evans, A. S., Carvalho, R. P. S., and Grossman, L., EBV infections in Brazil. III. Infectious mononucleosis, Unpublished (1974).

49. Evans, A. S., Evans, B. K., and Sturtz, V., Standards for hepatic and hematologic tests in monkeys: Observations during experiments with hepatitis and mononucleosis, Proc. Soc. Exp. Biol. Med. 82:437-440 (1953).

50. Evans, A. S., Niederman, J. C., and McCollum, R. W., Seroepidemiological studies of infectious mono- nucleosis with EB virus, N. Engl. J. Med. 279:1121-1127 (1968).

51. Evans, A. S., Jensen, R., Niederman, J. C., AND Wallace, D. K., Studies of EBV antibody in Fort Jackson military recruits, Unpublished data (1974).

52. Evans, A. S., Niederman, J. C., Cenabre, L. C., WEST, B., AND RIChARDS, V. A., A prospective evaluation of heterophile and Epstein-Barr virus-specific IgM antibody tests in clinical and subclinical infectious mononucleosis: Specificity and sensitivity of the tests and persistence of antibody, J. Infect. Dis. 132:546-554 (1975).

53. Filatov, N. F., Semiotik and Diagnotik de Kinderkrankheiten, Verlag von Ferdinand Enke, Stuttgart, 1892.

54. Filatov, N. F., Lektuse ob ostrikh infektsion nikh lolieznyak (Lectures on acute infectious diseases of children), Moscow, U Deitel, 1885; cited by Wising, P. J., Acta Med. Scand. Suppl. 133:1-102 (1942).

54a. Fleischer, G., Lennette, E. T., Henle, G., AND HENLE, W., Incidence of heterophile antibody responses in children with infectious mononucleosis, J. Pediatr. 94:723-728 (1979).

55. Gardner, H. T., AND PaUl, J. R., Infectious mononucleosis at the New Haven Hospital, 1921-46, Yale J. Biol. Med. 19:839-853 (1947).

56. Gerber, P., and Deal, D. R., Epstein-Barr virus-induced viral and soluble complement-fixing antigens in Burkitt lymphoma cell cultures, Proc. Soc. Exp. Biol. Med. 134:748-751 (1970).

57. Gerber, P., AND Rosenblum, E. N., The incidence of complement-fixing antibodies to herpes simplex and herpes-like viruses in man and rhesus monkeys, Proc. Soc. Exp. Biol. Med. 128:541-546 (1968).

58. Gerber, P., Purcell, R. H., Rosenblum, E. N., and WALSH, J. H., Association of EB-virus infection with the post-perfusion syndrome, Lancet 1:593-596 (1969).

59. Gerber, R., Goldstein, L. I., Lucas, S., Nonoyama, M., AND Perlin, E., Oral excretion of Epstein-Barr viruses by healthy subjects and patients with infectious mononucleosis, Lancet 2:988-989 (1972).

59a. Gerber, P., Nkrumah, F. K., Pritchett, R., and KIEFF, E., Comparative studies of Epstein-Barr virus strains from Ghana and the United States, Int. J. Cancer 17:71-81 (1976).

59b. Ginsburg, C. M., Henle, W., Henle, G., and HorWITZ, C. A., Infectious mononucleosis in children: Evaluation of Epstein-Barr virus specific serological data, J. Am. Med. Assoc. 237:781-785 (1977).

59c. Ginsburg, C. M., Henle, G., and Henle, W., An outbreak of infectious mononucleosis among the personnel of an outpatient clinic, Am. J. Epidemiol. 104:571-575 (1976).

60. Giulano, V. J., Jasin, H. E., AND ZifF, M., The nature 
of the atypical lymphocyte in infectious mononucleosis, Clin. Immunol. Immunopathol. 3:90-98 (1974).

61. Grace, J. T., Blakeslee, J., and Jones, R., Induction of infectious mononucleosis in man by the herpestype virus (HTV) in Burkitt lymphoma cells in tissue culture, Proc. Am. Assoc. Cancer Res. 10:31 (1969).

61a. Grose, C., Henle, W., Henle, G., and Feorino, P. M., Primary Epstein-Barr infections in acute neurologic disease, N. Engl. J. Med. 292:392-393 (1975).

62. Haider, S., Coutinho, M. D., AND EMOND, R. T. D., Tuberculin anergy and infectious mononucleosis, Lancet 2:74 (1973).

63. Hainebach, J., II. Beitrag zur Aetiologie des Pfeiffer'schen Drüsenfiebers, Dtsch. Med. Wochenschr. 26:419-420 (1899).

64. Halcrow, J. P. A., Owen, L. M., And Roger, N. O., Infectious mononucleosis with an account of an epidemic in E.M.S. hospital, Br. Med. J. 2:443-447 (1943).

65. Hallee, T. J., Evans, A. S., Niederman, J. C., BROOKS, C. M., AND Voegtly, J. H. Infectious mononucleosis at the U.S. Military Academy: A prospective study of a single class over four years, Yale J. Biol. Med. 47:182-195 (1974).

65a. Hamilton, J. K., Sullivan, J. L., Maurer, H. S., Cruzi, F. G., Proirson, A. J., Stenke, K., FinkelStein, G. Z., Landing, B., Grunnet, M., and PurTILO, D. T., X-linked lymphoproliferative syndrome registry report, J. Pediatr. 4:669-673 (1980).

66. Hampar, B., Hsu, K. C., Martos, L. M., AND WALKER, J. L., Serologic evidence that a herpes-type virus is the etiologic agent of heterophile-positive infectious mononucleosis, Proc. Natl. Acad. Sci. U.S.A. 68:1407-1411 (1971).

67. Hardy, D. A., AND Steel, C. M., Cytotoxic potential of lymphocytes stimulated with autochthonous lymphoid cell lines, Experientia 27:1336-1338 (1971).

68. HeAth, C. W., BRODSKY, A. L., AND POTOLSKY, A. I., Infectious mononucleosis in a general population, Am. J. Epidemiol. 95:46-52 (1972).

68a. Haynes, B. F., Schooley, R. T., Playing-Wright, C. R., Grouse, J. E., Dolin, R., ANd FaucI, A. S. Emergence of suppressor cells of immunoglobulin synthesis during acute Epstein-Barr-virus-induced infectious mononucleosis, J. Immunol. 123:2095-2101 (1979).

68b. Haynes, B. F., Schooley, R. T., Grouse, J. E., PlayING-Wright, C. R., Dolin, R., AND FaUCI, A. S., Characterization of thymus-derived lymphocyte subsets in acute Epstein-Barr virus induced infectious mononucleosis, J. Immunol. 122:699-702 (1979).

68c. Henderson, E., Miller, G., Robinson, J., and HesTON, L., Efficiency of transformation of lymphocytes by Epstein-Barr virus, Virology 76:152-163 (1977). 68d. Henderson, E., Heston, L., Grogan, E., and Miller, G., Radiobiological inactivation of Epstein-Barr virus, J. Virol. 25:51-59 (1978).

69. Henke, C. E., Kurland, L. T., and Elveback, L. R., Infectious mononucleosis in Rochester, Minn., 1950 through 1969, Am. J. Epidemiol. 98:483-490 (1973).

70. Henle, G., AND Henle, W., Immunofluorescence in cells derived from Burkitt's lymphoma, J. Bacteriol. 91:1248-1256 (1966).

71. Henle, G., and Henle, W., Observations on childhood infections with Epstein-Barr virus, J. Infect. Dis. 121:303-310 (1970).

72. Henle, G., Henle, W., and Diehl, V., Relation of Burkitt's tumor-associated herpes-type virus to infectious mononucleosis, Proc. Natl. Acad. Sci. U.S.A. 59:94-101 (1968).

73. Henle, G., Henle, W., And Horwitz, C. A., Antibodies to Epstein-Barr virus-associated nuclear antigen in infectious mononucleosis, J. Infect. Dis. 130:231-239 (1974).

73a. Henle, W., Henle, G., and Horwitz, C. A., Epstein-Barr virus specific diagnostic tests in infectious mononucleosis, Hum. Pathol. 5:551-565 (1974).

74. Henle, G., Henle, W., And Klein, G., Demonstration of two distinct components in the early antigen complex of Epstein-Barr virus-infected cells, Int. J. Cancer 8:272-282 (1971).

75. Henle, W., Henle, G., Harrison, F. S., Joyner, C. R., Klemola, E., Paloheimo, J., Scriba, M., and von EsSEN, F., Antibody responses to the Epstein-Barr virus and cytomegaloviruses after open-heart and other surgery, N. Engl. J. Med. 282:1068-1074 (1968).

76. Henle, W., Henle, G., Pearson, G., Scriba, M., WaubKe, R., AND ZaJAC, B. A., Differential reactivity of human serums with early antigens induced by Epstein-Barr virus, Science 169:188-190 (1970).

77. Henle, W., Henle, G., Niederman, J. C., Haltia, K., AND Klemola, E., Antibodies to early antigens induced by Epstein-Barr virus in infectious mononucleosis, J. Infect. Dis. 124:58-67 (1971).

78. Hewetson, J. F., Rochi, G., Henle, W., and Henle, G., Neutralizing antibodies to Epstein-Barr virus in healthy populations and patients with infectious mononucleosis, J. Infect. Dis. 128:283-389 (1973).

79. Hoagland, R. J., The transmission of infectious mononucleosis, Am. J. Med. Sci. 229:262-272 (1955).

80. Hoagland, R. J., Resurgent heterophil-antibody reaction after infectious mononucleosis, N. Engl. J. Med. 269:1307-1308 (1963).

81. Hoagland, R. J., The incubation period of infectious mononucleosis, Am. J. Public Health 54:1699-1705 (1964).

82. Hoagland, R., Infectious Mononucleosis, Grune and Stratton, New York, 1967. 
83. Hobson, F. G., Lawson, B., AND Wigfield, M., Glandular fever, a field study, $\mathrm{Br}$. Med. J. 1:845-852 (1958).

83a. Hoskins, T. W., Fletcher, W. B., Blake, J. M., PerEIRA, M. S., ANDEDWARDS, J. M. B., EB virus antibody and infectious mononucleosis in a boarding school for boys, J. Clin. Pathol. 29:42-45 (1976).

83b. Hutt, L. M., Huang, Y. T., Dascomb, H. E., AND PAGANO, J. S., Enhanced destruction of lymphoid cell lines by peripheral blood leucocytes taken from patients with acute infectious mononucleosis, J. Immunol. 115:243-248 (1975).

84. JENNINGS, E., Prevalence of EB virus antibody in Hawaii, M.D. thesis, Yale University School of Medicine, 1973.

85. Joncas, J., and Mitnyan, C., Serological response of the EBV antibodies in pediatric cases of infectious mononucleosis and in their contacts, Can. Med. Assoc. J. 102:1260-1263 (1970).

85a. Jondal, M., AND Klein, G., Surface markers on human B and T lymphocytes. II. Presence of Epstein-Barr virus receptors on B lymphocytes, J. Exp. Med. 138:1365-1378 (1973).

85b. Jondal, M., Klein, G., Oldstone, M. B. S., BoKish, V., AND YEFENOF, E., Surface markers on human B and T lymphocytes. VII. Association between complement and Epstein-Barr virus receptors on human lymphoid lines, Scand. J. Immunol. 5:401-410 (1976).

86. JoRdAN, W. S., AND Albright, R. W., Liver function tests in infectious mononucleosis, J. Lab. Clin. Med. 35:688-698 (1950).

87. Junge, U., Deinhardt, F., ANd Hoekstra, J., Stimulation of peripheral lymphocytes by allogeneic and autochthonous mononucleosis lymphocyte cell lines, J. Immunol. 106:1306-1315 (1971).

87a. Kano, K., and Milgrom, F., Heterophile antigens and antibodies in medicine, Current Top. Microbiol. Immunol. 77:43-69 (1977).

88. Klein, G., Klein, E., Clifford, P., and Sternsward, G., Search for tumor specific immune reactors in Burkitt lymphoma patients by the membrane immunofluorescence reaction, Proc. Natl. Acad. Sci. U.S.A. 55:1628-1635 (1966)

88a. Kassl, S. V., Evans, A. S., and Niederman, J. C. Psychosocial risk factors in the development of infectious mononucleosis, Psychosom. Med. 41:445-466, 1979.

89. Klein, G., Lindahl, T., Jondal, M., Leibolb, W., Menézes, J., Nilsson, K., AND Sundström, C., Continuous lymphoid cell lines with characteristics of B cells (bone-marrow-derived) lacking the Epstein-Barr virus genome, and derived from three human lymphomas, Proc. Natl. Acad. Sci. U.S.A. 71:3283-3286, (1974)
90. Klein, G., Diehl, V., Henle, G., Henle, W., PearSON, G., AND NeIDERMAN, J. C., Relations between Epstein-Barr viral and cell membrane immunofluorescence in Burkitt tumor cells. II. Comparison of cells and sera from patients with Burkitt's lymphoma and infectious mononucleosis, J. Exp. Med. 128:1021-1030 (1968).

90a. Klein, G., Svedmvy, E., Jondal, M., and Persson, P. O., EBV-determined nuclear antigen (EBNA)-positive cells in the peripheral blood of infectious mononucleosis patients, Int. J. Cancer 17:21-26 (1976).

91. Klemola, E., Henle, G., Henle, W., ANd von Essen, R., Infectious mononucleosis-like disease with negative heterophile agglutination test: Clinical features in relation to Epstein-Barr virus and cytomegalovirus antibodies, J. Infect. Dis. 121:608-614 (1970).

92. LANG, D. J., AND HaNSHAW, J. B., Cytomegalovirus infection and the postperfusion syndrome: Recognition of primary infection in four patients, N. Engl. J. Med. 280:1145-1149 (1969).

93. LeE, C. L., Davidsohn, I., AND Slaby, R., Horse agglutinins in infectious mononucleosis. Am. J. Clin. Pathol. 49:3-11 (1968).

94. Lehane, D. E., A seroepidemiologic study of infectious mononucleosis: The development of EB virus antibody in a military population, J. Am. Med. Assoc. 212:2240-2242 (1970).

94a. Lemon, S. M., Hutt, L. M., Shaw, J. C., Li, J. H., AND PAGANO, J. H., Replication of EBV in epithelial cells during infectious mononucleosis, Nature (London) 268:268-270 (1977).

94b. Lemon, S. M., Hutt, L. M., Huang, Y., Blum, J., AND PAGANO, J. H., Simultaneous infection with multiple herpesviruses, Am. J. Med. 66:270-276 (1979).

94c. Lennette, E. T., Henle, G., Henle, W., And HorowITZ, C. A., Heterophil antigen in bovine sera detectable by immune adherence hemagglutination with infectious mononucleosis sera, Infect. Immun. 19:923-927 (1978).

95. Liebowitz, S., Infectious Mononucleosis, Grune and Stratton, New York, 1953.

96. LONGCOPE, W. T., Infectious mononucleosis (glandular fever), with a report of ten cases, Am. J. Med. Sci. 164:781-807 (1922).

97. Mangi, R., Niederman, J. C., Kelleher, J. E., Dwyer, J. M., Evans, A. S., AND Kantor, F. S., Depression of cell-mediated immunity during acute infectious mononucleosis, N. Engl. J. Med. 291:1149-1153 (1974).

98. MAsON, K. L., An ox cell hemolysin test for the diagnosis of infectious mononucleosis, J. Hyg. 49:471-481 (1951).

99. Maurer, B. A., IMAMURA, T., AND Wilbert, S. M., Incidence of EB virus containing cells in primary and 
secondary clones of several Burkitt lymphoma cell lines, Cancer Res. 30:2870-2875 (1970).

100. Miller, G., The oncogenicity of Epstein-Barr virus, J. Infect. Dis. 130:187-205 (1974).

100a. Miller, G., Biology of Epstein-Barr virus, in: Viral Oncology (G. KLEIN, ed.), pp. 713-738, Raven Press, New York, 1980.

101. Miller, G., and Heston, L., Expression of Epstein-Barr viral capsid, complement fixing and nuclear antigens in stationary and exponential phase cultures, Yale J. Biol. Med. 47:123-135 (1974).

102. Miller, G., AND Lipman, M., Release of infectious Epstein-Barr virus by transformed marmoset leucocytes, Proc. Natl. Acad. Sci. U.S.A. 70:190-194 (1973).

103. Miller, G., Niederman, J. C., ANd Andrews, L. L., Prolonged oropharyngeal excretion of Epstein-Barr virus after infectious mononucleosis, N. Engl. J. Med. 288:229-232 (1973).

104. Miller, G., Miller, M. H., ANDStitT, D., Epstein-Barr viral antigen in single cell clones of two human leucocytic lines, J. Virol. 6:699-701 (1970).

105. Miller, G., Niederman, J. C., ANd Stitt, D. A., Infectious mononucleosis: Appearance of neutralizing antibody to Epstein-Barr virus measured by inhibition of formation of lymphoblastoid cell lines, $J$. Infect. Dis. 125:403-406 (1972).

106. Miller, G., Robinson, J., Heston, L., and Lipman, M., Differences between laboratory strains of Epstein-Barr virus based on immortalization, abortive infection and interference, Proc. Natl. Acad. Sci. U.S.A. 71:4006-4010 (1974).

107. MoIR, J. I., Glandular fever in the Falkland Islands, Br. Med. J. 2:822-823 (1930).

107a. Mori, T., KANO, K., AND Milgrom, F., Formation of Paul Bunnell antibodies by cultures of lymphocytes from infectious mononucleosis, Cell. Immunol. 34:289-298 (1977).

107b. Morgan, D. G., Niederman, J. C., Miller, G., Smith, H. W., AND Dowaliby, J. M., Site of Epstein-Barr virus replication in the oropharynx, Lancet 2:1154-1157 (1979).

108. Morse, P. F., Glandular fever, J. Am. Med. Assoc. 77:1403-1404 (1921).

108a. Muñoz, N., DavidSon, R. J. K., Witthoff, B., ERICSSON, J. E., AND DE THE, G., Infectious mononucleosis and Hodgkin's disease, Int. J. Cancer 22:10-13 (1978).

109. Newall, K. W., The reported incidence of glandular fever, and analysis of a report of the Public Health Laboratory Service, J. Clin. Pathol. 10:20-22 (1957).

110. NiEDERMAN, J. C., Infectious mononucleosis at the Yale-New Haven Medical Center, 1946-1955, Yale J. Biol. Med. 28:629-643 (1956).

111. Niederman, J. C., The presence of EBV antibody in sera from volunteers in infectious mononucleosis transmission attempts prior to inoculation, Unpublished work (1969).

112. Niederman, J. C., AND Scott, R. B., Studies on infectious mononucleosis: Attempts to transmit the disease to human volunteers, Yale J. Biol. Med. 38:1-10 (1965).

113. Niederman, J. C., Evans, A. S., McCollum, R. W., and Subrahmanyan, L., Prevalence, incidence and persistence of EB virus antibody in young adults, $N$. Engl. J. Med. 282:361-365 (1970).

114. Niederman, J. C., McCollum, R. W., Henle, G., AND HeNle, W., Infectious mononucleosis: Clinical manifestations in relation to EB virus antibodies, $J$. Am. Med. Assoc. 203:205-209 (1968).

114a. Niederman, J. C., Miller, G., Pearson, H. A., PaGANO, J. S., AND DowalibY, J. M., Infectious mononucleosis: Epstein-Barr shedding in saliva and the oropharynx, N. Engl. J. Med. 294:1355-1359 (1976).

114b. Nikoskelainen, J., Leikola, J., and Klemola, E., IgM antibodies specific for Epstein-Barr virus in infectious mononucleosis without heterophile antibodies, Br. Med. J. 4:72-75 (1974).

114c. Nikoskelainen, J. J., Ablashi, D. V., Isenberg, R. A., Neel, E. U., Miller, R. G., and Stevens, D. A., Cellular immunity in infectious mononucleosis. II. Specific reactivity to Epstein-Barr virus antigens and correlation with clinical and hematologic parameter, I. Immunol. 121:1239-1244 (1978).

115. Nonoyama, M., and Pagano, J. S., Homology between Epstein-Barr virus DNA and viral DNA from Burkitt's lymphoma and nasopharyngeal carcinoma determined by DNA-DNA reassociation kinetics, Nature (London) 242:44-47 (1973).

116. Old, L. J., Clifford, P., Boyse, E. A., DeHarven, E., Geering, G., Oettgen, H. F., and Williamson, B., Precipitating antibody in human serum to an antigen present in cultured Burkitt lymphoma cells, Proc. Natl. Acad. Sci. U.S.A. 56:1699-1704 (1966).

117. Pagano, J. S., The Epstein-Barr viral genome and its interactions with human lymphoblastoid cells and chromosomes, in: Viruses, Evolution and Cancer (K. Maramorosch and E. KurstaK, eds.), 79-116, Academic Press, New York, 1974.

117a. Pannuti, C. S., Carvalho, R. P. S., Evans, A. S., Cenabre, L. C., Neto, A., Camargo, M., Angelo, M. J. P., AND TAKimoto, S., A prospective clinical study of the mononucleosis syndrome in a developing country, Int. J. Epidemiol. 9:349-353 (1980).

118. Pattengale, P. K., Gerber, P., and Smith, R. W., Selective transformation of B lymphocytes by EB virus, Lancet 2:1153-1155 (1973).

119. Pattengale, P. K., Gerber, P., and Smith, R. W., Bcell characteristics of human peripheral and cord 
blood lymphocytes transformed by Epstein-Barr virus, J. Natl. Cancer Inst. 52:1081-1086 (1974).

120. Pattengale, P. K., Smrth, R. W., and Perlin, E., Atypical lymphocytes in acute infectious mononucleosis, N. Engl. J. Med. 291:1145-1148 (1974).

121. Paul, J. R., AND Bunnell, W. W., The presence of heterophile antibodies in infectious mononucleosis, Am. J. Med. Sci. 183:91-104 (1932).

122. PAUL, O., Mononucleosis on board a destroyer, U.S. Naval Med. Bull. 44:614-617 (1945).

123. Pearson, G., Dewey, F., Klein, G., Henle, G., and HENLE, W., Relation between neutralization of Epstein-Barr virus and antibodies to cell membrane antigens induced by the virus, J. Natl. Cancer Inst. 45:989-995 (1970).

124. Pereira, M. S., Blake, J. M., and Macrae, A. D., EB virus antibody at different ages, Br. Med. J. 4:526-527 (1969).

125. Pereira, M. S., Field, A. M., Blake, J. M., Rodgers, F. G., BAILEY, L. A., AND DAvies, J. R., Evidence for oral excretion of E.B. virus in infectious mononucleosis, Lancet 1:710-711 (1972).

126. Pfeiffer, E., DRÜSEnFIEBER, Jahrb. Kinderheilkd. 29:257-264 (1889)

127. Pope, J. H., Horne, M. K., ANd Wetters, E. J., Significance of a complement-fixing antigen associated with herpes-like virus and detected in the Raji cell line, Nature (London) 228:186-187 (1969).

128. Pulvertaft, R. J. X., Cytology of Burkitt's tumor (African lymphoma), Lancet 1:238-240 (1964).

128a. Purtilo, D. T., Bhawan, J., Hutt, L. M., De Nicola, L., Szymanski, I., Yang, J. P. S., Boto, W., Maier, R., AND THORLEY-LAWSON, D., Epstein-Barr virus infections in the $\mathrm{X}$-linked recessive lymphoproliferative syndrome, Lancet 1:798-801 (1978).

128b. Purtilo, D. T., Hutt, L, Bhawan, J., Yang, J. P. S., Cassel, C., Allegro, S., and Rosen, F. S., Immunodeficiency to the Epstein-Barr virus in the $X$ linked recessive lymphoproliferative syndrome, Clin. Immunol. Immunopathol. 9:147-156 (1978).

128c. Qualtiere, L. F., AND Pearson, G. R., Solubilization of Epstein-Barr virus induced membrane antigen by limited papain digestion, Fed. Proc. Fed. Am. Soc. Exp. Biol. 37:1817 (1978).

129. Reedman, B. M., and Klein, G., Cellular localization of an Epstein-Barr virus (EBV) associated complement-fixing antigen in producer and non-producer lymphoblastoid cell lines, Int. J. Cancer 11:499-520 (1973).

129a. RoBinson, J., AND Miller, G., Assay for Epstein-Barr virus based on stimulation of DNA synthesis in mixed leukocytes from human umbilical cord blood, J. Virol. 15:1065-1072 (1975)

129b. Robinson, J. E., Brown, N., Andiman, W., Halliday, K., Francke, U., Robert, M. F., ANDersson-
Anvret, M., Horstmann, D., AND Miller, G., Diffuse polyclonal B-cell lymphoma during primary infection with Epstein-Barr virus, New Engl. J. Med. 320:1293-1296 (1980).

130. Rocchi, G., Hewetson, J., AND Henle, W., Specific neutralizing antibodies in Epstein-Barr virus associated diseases, Int. J. Cancer 11:637-647 (1973).

130a. Rocchi, G., de Felici, A., Ragona, G., and Heinz, A., Quantitative evaluation of Epstein-Barr-virusinfected mononuclear peripheral blood leukocytes in infectious mononucleosis, N. Engl. J. Med. 296:132-134 (1977).

131. Rosalki, S. B., LwynN, J. T., ANd Verney, P. T., Transaminase and liver function studies in infectious mononucleosis, Br. Med. J. 1:929-932 (1960).

131a. Rosdahl, N., LaRsen, S. O., AND Thamdrup, B., Infectious mononucleosis in Denmark: Epidemiological observations based on positive Paul-Bunnell reactions 1940-1969, Scand. J. Infect. Dis. 5:163-170 (1973).

131b. Rosen, A., Gergely, P., Jondal, M., and Klein, G., Polyclonal Ig production after Epstein Barr virus infection of human lymphocytes in vitro, Nature (London) 267:52 (1977).

131c. Royston, I., Sullivan, J. L., Periman, P. O., and PerLIN, E., Cell-mediated immunity to Epstein-Barr virus-transformed lymphoblastoid cells in acute infectious mononucleosis, N. Engl. J. Med. 293:1159-1163 (1975).

132. SAwYer, R. N., Evans, A. S., Niederman, J. C., AND McCollum, R. W., Prospective studies of a group of Yale University freshmen. I. Occurrence of infectious mononucleosis, J. Infect. Dis. 123:263-269 (1971).

132a. SCHIFF, J., SchaefFer, J., AND ROBINSON, J., Cell-associated Epstein-Barr virus in the cerebrospinal fluid of a patient with meningoencephalitis complicating infectious mononucleosis, Personal communication (1978).

132b. Schiller, J., AND Davey, F. R., Human leukocyte locus A (HL-A antigens and infectious mononucleosis, Am. J. Clin. Pathol. 62:325-328 (1974).

133. SCHMITZ, H., AND SCHERER, M., IgM antibodies to Epstein-Barr virus in infectious mononucleosis, Arch. Gesamte Virusforsch. 37:332-339 (1972).

134. Sheldon, P. J., Hemsted, E. H., Holborow, E. J., AND PaPAmichael, M., Thymic origin of atypical lymphocytes in infectious mononucleosis, Lancet 2:1153-1155 (1973).

135. Shope, T., AND Miller, G., Epstein-Barr virus, heterophile responses in squirrel monkeys inoculated with virus-transformed autologous leucocytes, $J$. Exp. Med. 137:140-147 (1973).

136. Shope, T., Evans, A. S., and Horstmann, D. M., Seroconversion rates of EBV antibody in New Haven 
school children by socio-economic level, Unpublished studies (1973).

136a. Smith, H., AND Denman, A. M., A new manifestation of infection with Epstein-Barr virus, Br. Med. J. 2:248-249 (1978).

137. Sohier, R., Lepine, P., and Sautter, V., Recherches sur la transmission experimentale de la mononucleose au singe et a l'homme, Ann. Inst. Pasteur 65:50-62 (1940).

138. SoHIER, R., La Mononucleose Infectieuse, Masson et Cie, Paris, 1943.

139. Sprunt, T. P., ANd Evans, F. A., Mononuclear leukocytosis in reaction to acute infections (in infectious mononucleosis), Bull. Johns Hopkins Hosp. 31:410-417 (1920).

140. SteEl, C. M., AND LiNG, N. R., Immunopathology of infectious mononucleosis, Lancet 2:861-862 (1973).

141. Stevenson, E. M. K., AND Brown, T. G., Infectious mononucleosis: Preliminary investigation of a series of cases, Glasgow Med. J. 140:139-150 (1943).

142. Storkie, M. D., Sawyer, R. N., Sphar, R. L., AND Evans, A. S., Seroepidemiological studies of Polaris submarine crews. II. Infectious mononucleosis, Mil. Med. 141:30-33 (1976).

143. Strauch, B., Andrews, L., Miller, G., and Siegel, N., Oropharyngeal excretion of Epstein-Barr virus by renal transplant recipients and other patients treated with immunosuppressant drugs, Lancet 1:234-237 (1974).

144. StRÖM, J., Infectious mononucleosis-Is the incidence increasing?, Acta Med. Scand. 168:35-39 (1960).

144a. SumayA, C. V., Primary Epstein-Barr virus infections in children, Pediatrics 59:16-21 (1977).

145. TAYLOR, A. W., Effects of glandular fever in acute leukemia, Br. Med. J. 1:589-593 (1953).

146. Thomsen, S., Studier over Mononucleosis Infectiosa, Munksgaard, Copenhagen, 1942.

146a. Thorley-Lawson, D. A., Chess, L., ANDStrominger, J. L., Suppression of in vitro Epstein-Barr virus infection: A new role for adult human T lymphocytes, J. Exp. Med. 146:495-507 (1977).

147. Tischendorf, P., Balagtas, R. C., Deinhardt, F., Knospe, W. H., Maynard, J. E., Noble, G. R., and ShrameK, G. J., Development and persistence of immunity to Epstein-Barr virus in man, J. Infect. Dis. 122:401-409 (1970).

147a. Tosato, G., Magrath, I., Koski, I., Dooley, N., AND BlAESE, M., Activation of suppressor T cells during Epstein-Barr-virus induced infectious mononucleosis, N. Engl. J. Med. 301:1133-1137 (1979).

148. University Health Physicians and P.H.L.S. LaboRATORIES, A joint investigation: Infectious mononucleosis and its relationship to EB virus antibody, $\mathrm{Br}$. Med. J. 4:643-646 (1971).

149. Vandermeer, R., Lutterloh, C. H., and Pilot, J., Infectious mononucleosis: An analysis of 26 clinical and 340 subclinical cases, Am. J. Med. Sci. 210:765-774 (1945).

149a. Veltri, R. W., McClung, J. E., AND Sprinkle, P. M., EBV antigens in lymphocytes of patients with exudative tonsillitis, infectious mononucleosis and Hodgkin's disease, Int. J. Cancer 21:683-687 (1978).

149b. Veltri, R. W., McClung, J. E., and Sprinkle, P. M., Epstein-Barr nuclear antigen (EBNA) carrying lymphocytes in human palatine tonsils, J. Gen. Virol. 32:455-460 (1976).

149c. Visintine, A. M., Gerber, P., and Nahmias, A. J., Leucocyte transforming agent (Epstein-Barr virus) in newborn infants and older individuals, J. Pediatr. 89:571-575 (1976).

150. Virolainen, M., Anderson, L. C., Lalla, M., AND VON ESSEN, R., T-lymphocyte proliferation in mononucleosis, Clin. Immunol. Immunopathol. 2:114-120 (1973).

151. Wahren, B., Espmark, A., Lantorp, K., and SterNER, G., EBV antibodies in family contacts of patients with infectious mononucleosis, Proc. Soc. Exp. Biol. Med. 133:934-939 (1970).

152. Walters, M. K., AND Pope, J. H., Studies of the EB virus-related antigens of human leucocyte cell lines, Int. J. Cancer 8:32-40 (1971).

153. Wechsler, H. F., Rosenblum, A. H., and Sills, C. T., Infectious mononucleosis: Report of an epidemic in an army post, Ann. Intern. Med. 25:113-133, 236-265 (1946).

154. Werner, J., Haff, R. F., Henle, G., Henle, W., and PINTO, C. A., Responses of gibbons to inoculation of Epstein-Barr virus, J. Infect. Dis. 126:678-681 (1972).

154a. Yefenof, E., BaKacs, T., Einhorn, L., Ernberg, I., AND KeLIN, G., Epstein-Barr virus (EBV) receptors, complement receptors and EBV infectibility of different lymphocyte fractions of human peripheral blood, Cell. Immunol. 35:34-42 (1978).

155. West, J. P., An epidemic of glandular fever, Arch. Pediatr. 13:889-900 (1896).

156. WISING, P. J., A study of infectious mononucleosis (Pfeiffer's disease) from the etiological point of view, Acta Med. Scand. Suppl. 133:1-102 (1942).

157. Wöllner, D., Ueber die serologische Diagnose der infektiosen Mononukleose nach Paul-Bunnell mit nativen and fermentierten Hammel Erythrocyten. 2, Immunitaets Forsch. 112:290-308 (1955).

158. WROBLEWSKI, F., Increasing clinical significance of alterations in enzymes in body fluids, Ann. Intern. Med. 50:62-93 (1959).

159. ZaJAC, B. A., AND KoHN, G., Epstein-Barr virus antigens, marker chromosomes, and interferon production in clones derived from cultured Burkitt tumor cells, J. Natl. Cancer Inst. 45:399-406 (1970).

160. Zur Hausen, H. H., Clifford, P., Henle, G., Henle, W., Klein, G., Santesson, L., and Schulte-Hol- 
THAUSEN, H., EB-virus DNA in biopsies of Burkitt tumors and anaplastic carcinomas of the nasopharynx, Nature (London) 228:1056-1057 (1970).

161. Zur Hausen, H., Dorrier, K., Egger, H., SchulteHolthausen, H., AND Wolf, H., Attempts to detect virus-specific DNA in human tumors. II. Nucleic acid hybridizations with complementary RNA of human herpes group viruses, Int. J. Cancer 13:657-664 (1974).

\section{Suggested Reading}

Carter, R. L., and Penman, H. G. (eds.), Infectious Mononucleosis, Blackwell, Oxford, 1969.
Chervenick, P. A., Infectious mononucleosis, Dis.-Mon. 1-56 (December 1974).

Evans, A. S., Infectious mononucleosis and related syndromes, Am. J. Med. Sci. 276:325-339 (1978).

Glade, P. R. (ed.), Infectious Mononucleosis, Lippincott, Philadelphia, 1973.

Henle, W., AND Henle, G., Epstein-Barr virus, Sci. Am. 241:48-59 (1979).

HoAgland, R., Infectious Mononucleosis, Grune and Stratton, New York, 1967.

KLeIN, G., The Epstein-Barr Virus in Herpesviruses (A. S. Kaplan, ed.), Academic Press, New York, 1973.

Miller, G., Epstein-Barr virus and infectious mononucleosis, Prog. Med. Virol. 20:84-112 (1975). 